\title{
Spectral study and classification of worldwide locations considering several multijunction solar cell technologies
}

Rubén Núñez*, Chen Jin, Marta Victoria, César Domínguez, Stephen Askins, Rebeca Herrero, Ignacio Antón and Gabriel Sala

Instituto de Energía Solar, Universidad Politécnica de Madrid, Madrid, Spain *ruben.nunez@ies-def.upm.es

1 Introduction .3

2 Data description. 5

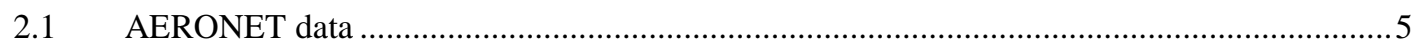

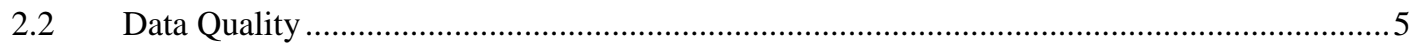

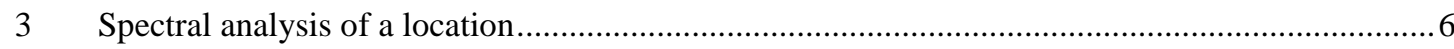

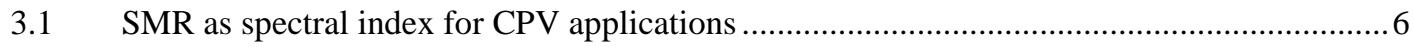

3.2 Annually DNI-weighted Spectral Matching Ratio ......................................................... 7

3.3 Experimental validation. Case study: Madrid ................................................................. 8

4 Mapping the solar resource with the spectral characteristics of worldwide locations ................... 9

4.1 Annually DNI-weighted top-middle SMR vs. geographic parameters ............................... 10

4.2 Annually DNI-weighted middle-bottom SMR vs. geographic parameters ......................... 11

4.3 Relationship between spectral parameters and SMRs....................................................... 11

$5 \quad$ Global analysis of spectral influence for several kinds of triple junction cells ........................15

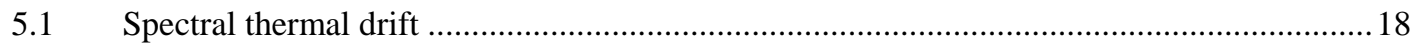

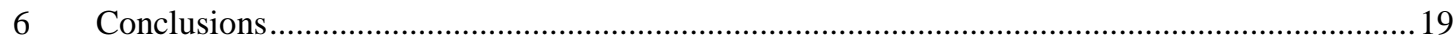

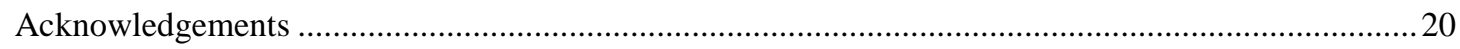

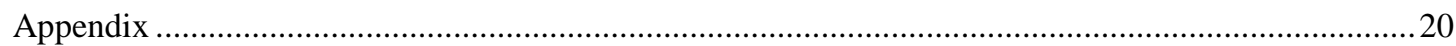

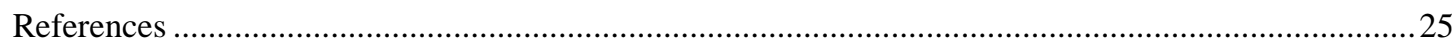

"This is the peer reviewed version of the following article: R. Núñez, C. Jin, M. Victoria, C. Domínguez, S. Askins, R. Herrero, I. Antón, and G. Sala, "Spectral study and classification of worldwide locations considering several multijunction solar cell technologies: Spectral study and classification of worldwide locations," Prog. Photovolt: Res. Appl., 2016, which has been published in final form at http://onlinelibrary.wilev.com/doi/10.1002/pip.2781/full. This article may be used for non-commercial purposes in accordance with Wiley Terms and Conditions for Self-Archiving 
Abstract: Multi-junction solar cells are widely used in high-concentration photovoltaic systems (HCPV) attaining the highest efficiencies in photovoltaic energy generation. This technology is more dependent on the spectral variations of the impinging Direct Normal Irradiance (DNI) than conventional photovoltaics based on silicon solar cells and consequently demands a deeper knowledge of the solar resource characteristics. This article explores the capabilities of spectral indexes, namely, spectral matching ratios (SMR), to spectrally characterize the annual irradiation reaching a particular location on the Earth and to provide the necessary information for the spectral optimization of a MJ solar cell in that location as a starting point for CPV module spectral tuning. Additionally, the relationship between such indexes and the atmosphere parameters, such as the aerosol optical depth (AOD), precipitable water (PW), and air mass (AM), is discussed using radiative transfer models such as SMARTS to generate the spectrally-resolved DNI. The network of ground-based sun and sky-scanning radiometers AERONET (AErosol RObotic NETwork) is exploited to obtain the atmosphere parameters for a selected bunch of 34 sites worldwide. Finally, the SMR indexes are obtained for every location, and a comparative analysis is carried out for four architectures of triple junction solar cells, covering both lattice match and metamorphic technologies. The differences found among cell technologies are much less significant than among locations.

Keywords: component cells; multijunction cells; concentrator photovoltaics; spectral characterization; worldwide analysis; cell temperature

"This is the peer reviewed version of the following article: R. Núñez, C. Jin, M. Victoria, C. Domínguez, S. Askins, R. Herrero, I. Antón, and G. Sala, "Spectral study and classification of worldwide locations considering several multijunction solar cell technologies: Spectral study and classification of worldwide locations," Prog. Photovolt: Res. Appl., 2016, which has been published in final form at http://onlinelibrarv.wilev.com/doi/10.1002/pip.2781/full. This article may be used for non-commercial purposes in accordance with Wiley Terms and Conditions for Self-Archiving 


\section{INTRODUCTION}

Concentrator photovoltaic (CPV) technology is based on the use of inexpensive optics to concentrate solar irradiance on a photovoltaic device. Concentration reduces the area of semiconductor for a given collecting aperture and enables the use of very high efficiency devices such as multi-junction (MJ) solar cells based on III-V compound semiconductors. These solar cells, developed initially for the aerospace industry, can be competitive in the terrestrial PV market when used in high-concentration PV systems (HCPV). A cumulative capacity of hundreds of MW of HCPV has already been installed and a significant increase is foreseen for the next years [1].

Two fundamental characteristics of HCPV systems are relevant regarding its use of the solar resource. On the one hand, only Direct Normal Irradiance (DNI) is exploited due to the limitation of the angular transmission of the optics. On the other hand, MJ cells are highly dependent on solar spectrum variations [2], [3] compared to single junction devices such as crystalline silicon solar cells. Since the subcells within a MJ solar cell are connected in series the subcell generating the least limits the current flowing through the device. Variations in the spectral distribution of the irradiance may introduce a mismatch between the currents photogenerated by every subcell in the stack and consequently limit the performance of the MJ solar cell. Therefore, a deeper characterization of the solar resource, and particularly the spectral variations caused by the atmosphere, is necessary for the design and performance estimation of MJ cells and the HCPV systems based on them.

Solar irradiance reaches the Earth's surface after the absorption and scattering caused by an atmosphere that is composed of distinct atmospheric components, each of them have a different impact on the final solar spectral irradiance distribution. To account for the influence of the atmosphere on the power generation of CPV systems, it is necessary to measure or estimate the spectral distribution of DNI, although some of these atmospheric components can influence CPV production without changing the solar spectrum but for example modifying the circumsolar radiation [4]. Direct measurement by means of spectroradiometers [5] has proved to be both very expensive and to require continuous maintenance and calibration to ensure accuracy. Alternatively, a simple and affordable method to characterize the solar resource is a set of component cells [6]-[9]. The so-called 'isotype' cells provide a very low spectral resolution, typically composed of three values, but enough to determine the performance of state-of-the-art CPV technologies. Although first experiences based on this approach have shown very good results [10], [11] and component cells and derived spectral parameters [9] are gaining prominence in the CPV community, worldwide data are not available for the evaluation of the potential generation of CPV systems, a gap that this paper intends to fill based on the MJ solar cells spectral impact.

An alternative approach for the atmosphere characterization involve the use of atmospheric radiative transfer models [12], such as SMARTS [13], SPECTRAL2 [14], and MODTRAN [15], which synthesize spectrally resolved DNI and GNI (Global Normal Irradiance) upon a particular atmospheric and environmental condition. The spectrally-resolved DNI is obtained by starting with the extraterrestrial irradiance, corrected by actual sun-earth distance, and considering atmospheric factors with a known impact on transmittance, namely, Rayleigh scattering, absorption by ozone, nitrogen dioxide, uniformly mixed gases and water vapor, and aerosol extinction. Among those factors, the

"This is the peer reviewed version of the following article: R. Núñez, C. Jin, M. Victoria, C. Domínguez, S. Askins, R. Herrero, I. Antón, and G. Sala, "Spectral study and classification of worldwide locations considering several multijunction solar cell technologies: Spectral study and classification of worldwide locations," Prog. Photovolt: Res. Appl., 2016, which has been published in final form at http://onlinelibrary.wiley.com/doi/10.1002/pip.2781/full. This article may be used for non-commercial purposes in accordance with Wiley Terms and Conditions for Self-Archiving [http://olabout.wiley.com/WileyCDA/Section/id-820227. html\#terms]." 
sunlight path length, which is function of Sun's zenith angle and altitude, the aerosol extinction and water vapor absorption are considered to be the principle impact factors [14], [16]-[21].

Therefore, based on a set of input parameters, primarily air mass (AM), aerosol optical depth (AOD), and precipitable water (PW), as well as geographical information (mainly altitude), radiative transfer models can provide the spectrally resolved DNI at a specific moment and location. Furthermore, a representative number of simulated spectral irradiance distributions can be used for estimating the average effect of the spectral variations in the performance of a MJ solar cell in periods of days, months, or a whole year for a specific site. This information is then used in this paper for the optimization of the current balance between subcells within a MJ solar cell under the standard reference spectrum, which will depend on the site.

The advantage of this approach is that satellite sources (MODIS [22] and SOLIS model [23], [24]) and a worldwide ground network with higher accuracy, AERONET [25] (AErosol RObotic NETwork), which provide the required atmospheric data are already available. AERONET is a network of ground-based sun photometers established by NASA and PHOTONS (PHOtométrie pour le Traitement Opérationnel de Normalisation Satellitaire) and it is greatly expanded by cooperation of research centers and individual scientists. The historical data and the wide geographical representation of the locations in the AERONET database have great value for the evaluation of part of the spectral variability relevant to $\mathrm{MJ}$ solar cells and consequently to CPV. These spectral data considering the locations with the most complete representative annual series are used in this work to estimate representative information of different climates and regions around the world.

The set of spectrally-resolved DNI for a number of sites and years, modeled with SMARTS from AERONET data, has been used to obtain spectral indexes used in CPV [26], [27] considering a representative operation cell temperature of $90{ }^{\circ} \mathrm{C}$. A second variant is considered at $25^{\circ} \mathrm{C}$ to estimate the spectral variation on MJ solar cell photocurrent due to thermal drift. Nevertheless an analysis of the influence in a concrete CPV system should also consider the effect of the optics on the spectral distribution on the MJ cell [28], the change on the transmittance due to temperature variations on the optics [29], [30] and ambient temperature fluctuations.

For the assessment and validation of this procedure, a comparison between spectral matching ratios (SMR) experimental values and those obtained by means of an atmospheric radiative transfer model (SMARTS) fed with AERONET data has been carried out for a whole year in Madrid considering lattice-matched based on germanium solar cells (LM-Ge). Furthermore, such spectral indexes and their annual DNI-weighted averages have been determined for a number of sites, namely 34 locations with representative AERONET data, to cover a wide and significant range of latitudes and altitudes to determine correlation between the SMRs and the site geographical features. This analysis is repeated for three more technologies, upright and inverted metamorphic solar cells (UMM and IMM) and lattice-matched with dilute nitride (LM-DN) solar cells, showing that all the annual DNI-weighted spectral parameters of different technologies have tiny differences at most of the locations.

"This is the peer reviewed version of the following article: R. Núñez, C. Jin, M. Victoria, C. Domínguez, S. Askins, R. Herrero, I. Antón, and G. Sala, "Spectral study and classification of worldwide locations considering several multijunction solar cell technologies: Spectral study and classification of worldwide locations," Prog. Photovolt: Res. Appl, 2016, which has been published in final form at http://onlinelibrary.wilev.com/doi/10.1002/pip.2781/full. This article may be used for non-commercial purposes in accordance with Wiley Terms and Conditions for Self-Archiving [http://olabout.wiley.com/WileyCDA/Section/id-820227.html/tterms]." 


\subsection{AERONET data}

The AERONET network is based on the instrument CIMEL Electronique 318A, which is a sky spectral sun photometer [31]-[33]. A sensor head fitted with collimators is attached to a robot base which systematically points the sensor at the sun disc and sky positions according to a programmed routine [25].

The radiometer makes two basic measurements, either sun disk or sky, both within several programmed sequences [25]. For the case of direct sunlight, the spectral irradiance at wavelengths of 340, 380, 440, 500, 670, 870, 940 and $1020 \mathrm{~nm}$ are measured (a sequence of three measurements are taken, creating a triplet per wavelength). The $940 \mathrm{~nm}$ channel is used for the determination of the atmospheric content of precipitable water (PW). Additionally, the attenuation induced by Rayleigh scattering and absorption by ozone and gaseous pollutants is estimated and removed to isolate the aerosol optical depth (AOD). This measurement is realized to screen the cases of influence of clouds. The typical time interval between measured data is 15 minutes.

\subsection{Data Quality}

The associated data published in the database of AERONET have three different levels, namely, level 1.0, level 1.5 and level 2.0 ordered by increasing level of data quality and reliability, but reducing the amount of available data.

In order to have a trade-off between reliable and representative results, data at level 1.5 (automatic cloud screened but no manual data inspection) are used for this study, considering one natural year as the time period unit. However, the data quality of each available location of AERONET is quite different considering the measurement frequency and the lack of data in a relatively long period, so a site analysis has been conducted to ensure very high data quality of the selected sites. It must be pointed out that the sun photometer does not generate data in cloudy conditions, so a lack of data caused by long cloudy periods or reliability and maintenance issues are indistinguishable. Nevertheless, these periods are of little relevance for CPV, as diffuse light is wasted.

Representative locations have been first selected according to data at level 2.0 because they are available on a single database (1.5 level data must be downloaded for each location separately). The database contains level 2.0 data of more than 800 locations, whose measured atmospheric parameters have different level of quality for each location and every year. The site and period selection criteria are set to be:

- A particular year must have at least a certain number of data points, fixed at 10000;

- Data must be available during each month of a year. All the sites are expected to have at least one sunny day per month even in winter conditions;

- $\quad$ Altitude of the site not exceeding $2000 \mathrm{~m}$;

- $\quad$ Latitude of site not exceeding 50 degrees.

To avoid a too limited set of sites, we have not considered an annual DNI threshold (even if some of them cannot be suitable for CPV). Nevertheless all of them provide valuable information about spectral differences. Under these criteria, 34 locations with at least one year of data were selected,

"This is the peer reviewed version of the following article: R. Núñez, C. Jin, M. Victoria, C. Domínguez, S. Askins, R. Herrero, I. Antón, and G. Sala, "Spectral study and classification of worldwide locations considering several multijunction solar cell technologies: Spectral study and classification of worldwide locations," Prog. Photovolt: Res. Appl., 2016, which has been published in final form at http://onlinelibrary. wilev.com/doi/10.1002/pip.2781/full. This article may be used for non-commercial purposes in accordance with Wiley Terms and Conditions for Self-Archiving [http://olabout.wiley.com/WileyCDA/Section/id-820227.htm/\#terms]." 
covering a wide range of climate conditions. The final set of locations can be seen in Figure 1 (the detailed list of selected locations is in the Appendix):

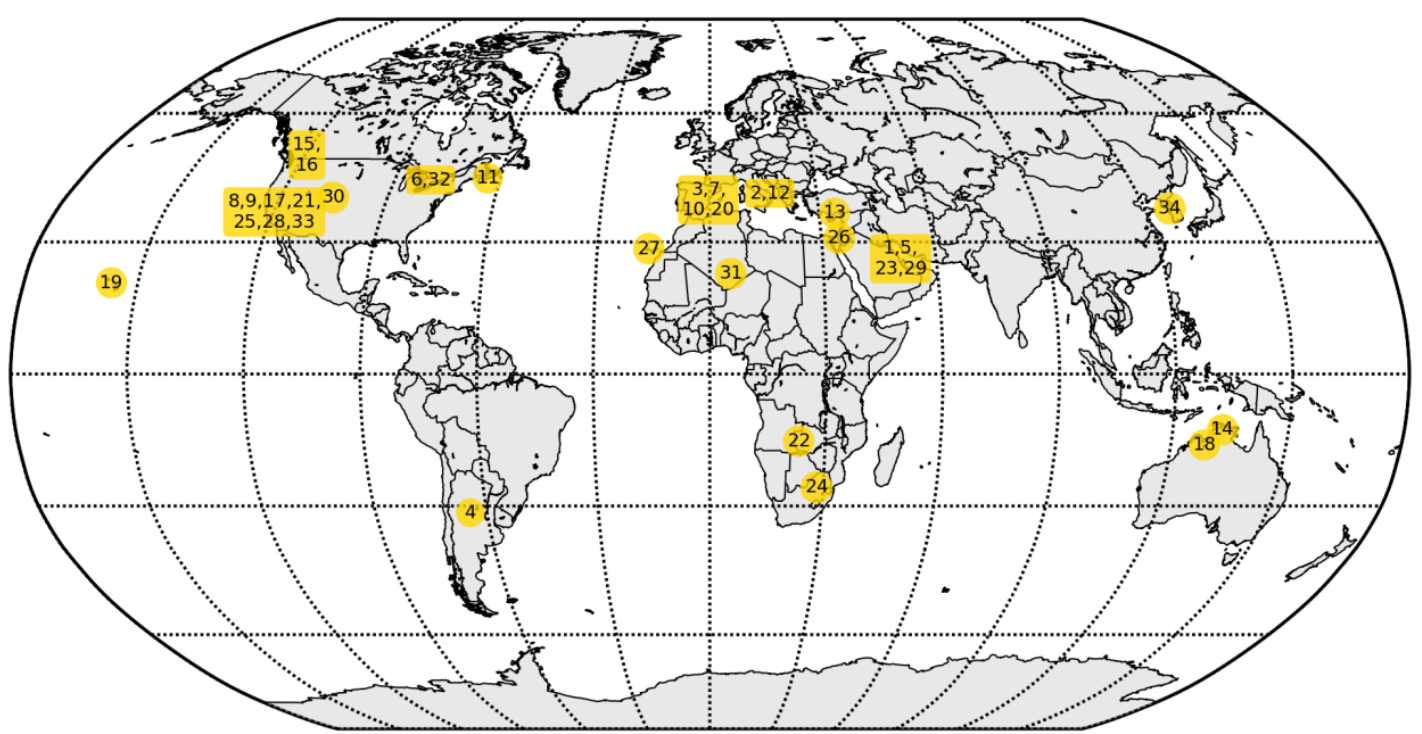

Figure 1 Worldwide distribution of selected AERONET locations. Note: numbers inside circles identify locations and can be found in Appendix.

\section{SPECTRAL ANALYSIS OF A LOCATION}

\subsection{SMR as spectral index for CPV applications}

A simple and affordable way to spectrally characterize the solar resource for CPV applications is a set of component cells [9]. In a component cell only one of the subcells is electrically active, while the others act as optical filters. Therefore a set of component cells provides an identical spectral response to the original MJ solar cell. This means that by just sensing a few photocurrent signals is possible to describe spectrally the DNI for a CPV system based on MJ cells of the same technology as the component cells. For the case of the widely used LM GaInP/GaInAs/Ge triple-junction (3J) solar cells, the spectral sensor consists of a set of three component cells installed in collimator tubes that track the Sun [9]. The complete instrument is known as spectroheliometer and the one used in the experimental part of this work was developed at the Instituto de Energía Solar of the Universidad Politécnica de Madrid (IES-UPM) in 2009. The instrument provides three photocurrent values (with an estimated uncertainty of the photocurrents of $\pm 3 \%$ [9]) each one corresponding to one of the subcells, $I_{\mathrm{L}, \text { top }}, I_{\mathrm{L}, \text { middle }}$ and $I_{\mathrm{L}, \mathrm{bottom}}$, which are the base for the calculation of spectral indexes (photocurrents are approximated by the short-circuit currents). The SMR [6] is an index that quantifies a particular irradiance spectrum by comparing it to the reference spectrum, i.e., AM1.5D given by the ASTM G173-03 norm [34]. The SMR index is technology dependent: it is defined as the ratio between the currents photogenerated by any two subcells $i$ and $j$ of a MJ stack under a particular spectrum, divided by their ratio under the reference spectrum:

"This is the peer reviewed version of the following article: R. Núñez, C. Jin, M. Victoria, C. Domínguez, S. Askins, R. Herrero, I. Antón, and G. Sala, "Spectral study and classification of worldwide locations considering several multijunction solar cell technologies: Spectral study and classification of worldwide locations," Prog. Photovolt: Res. Appl., 2016, which has been published in final form at http://onlinelibrary.wilev.com/doi/10.1002/pip.2781/full. This article may be used for non-commercial purposes in accordance with Wiley Terms and Conditions for Self-Archiving [http://olabout.wiley.com/WileyCDA/Section/id-820227.htm/\#terms]." 


$$
\operatorname{SMR}_{\text {subcell }_{\mathrm{j}}}^{\text {subcell }_{\mathrm{i}}}(\mathrm{ref}=\mathrm{AM} 1.5 \mathrm{D})=\frac{\mathrm{I}_{\mathrm{L}, \text { ratio }_{\text {subcell }_{\mathrm{j}}}}^{\text {subcel }_{\mathrm{j}}}}{\text { subcell }_{\text {ref }}}=\frac{\frac{\mathrm{I}_{\mathrm{L}, \text { subcell }_{\mathrm{i}}}}{\mathrm{I}_{\mathrm{L}, \text { subcell }_{\mathrm{j}}}}}{\mathrm{I}_{\mathrm{L}, \text { ratio }_{\text {subcell }_{\mathrm{j}}} \text { subcell }_{\text {ref }}}}
$$

where $\mathrm{I}_{\mathrm{L}, \text { subcell }}$ represents the photocurrent of the subcell $i$ when illuminated with a particular spectral irradiance distribution and $\mathrm{I}_{\mathrm{L} \text {,subcell }} \mathrm{i}_{\text {ref }}$ stands for the photoresponse of that subcell under the reference spectrum AM1.5D.

Considering, for example, a LM GaInP/GaInAs/Ge 3J cell, three spectral indexes can be defined: $\mathrm{SMR}_{\text {mid }}^{\text {top }}, \mathrm{SMR}_{\text {bot }}^{\text {top }}$ and $\mathrm{SMR}_{\text {bot }}^{\text {mid }}$, where the scripts top, mid and bot stands for the top GaInP subcell, the middle GaInAs subcell and the bottom Ge subcell respectively. Two of these SMRs (one is redundant) form a set of indexes that characterize the spectral irradiance for that particular MJ solar cell technology, consequently two spectra can be considered equivalent for the particular MJ solar cell when they attain the same SMRs. To put it another way, the subcells within a MJ solar cell show the same current ratios under any spectral condition with the same SMRs.

\subsection{Annually DNI-weighted Spectral Matching Ratio}

Based on the solar spectral irradiance obtained with SMARTS on the basis of the AERONET data and the quantum efficiencies (QE) of the MJ cells, a series of photocurrents for each subcell and the corresponding $\mathrm{SMR}_{\text {bot }}^{\text {top }}$ and $\mathrm{SMR}_{\text {bot }}^{\text {mid }}$ can be calculated for each selected location with the time resolution of the AERONET data (variable, maximum 15 minutes) and over a relevant period of time, namely one year at least filtering those whose SMR have no true meaning $(0<\mathrm{SMR}<1.5)$. Since $\mathrm{QE}$ are dependent on cell temperature, unless otherwise stated, hereafter a cell temperature of $90{ }^{\circ} \mathrm{C}$, closer to operation temperatures of MJ solar cells in a CPV module, will be considered. In addition, to characterize the spectral irradiance at a specific site, the average SMRs weighted by incident DNI for each location are calculated according to the following equations:

$$
\begin{gathered}
\overline{\mathrm{SMR}}_{\text {subcell }_{\mathrm{j}}}^{\text {subcell }_{\mathrm{i}}}=\frac{\sum_{\text {year }} \mathrm{SMR}_{\text {subcell }_{\mathrm{j}}}^{\text {subcell }_{\mathrm{i}}}(\mathrm{t}) \cdot \mathrm{DNI}_{P, A E R O N E T}(\mathrm{t})}{\sum_{\text {year }} \mathrm{DNI}_{P, A E R O N E T}(\mathrm{t})} \\
D N I_{P, A E R O N E T}(\mathrm{t})=\frac{\sum \mathrm{DNI}_{A E R O N E T}(\mathrm{t})}{\Delta \mathrm{t}}
\end{gathered}
$$

where $\overline{\mathrm{SMR}}_{\text {subcell }_{j}}^{\text {subcell }_{i}}$ is the annually DNI-weighted average $\mathrm{SMR}_{\text {subcell }_{j}}^{\text {subcell }_{i}} ; D N I_{P, A E R O N E T}$ stands for the representative DNI at the particular time period modeled with SMARTS from AERONET data; $\Delta t$ is the time resolution, which is calculated by the time difference between two consecutive measurements; usually 15 minutes but can be lower (i.e. it is assumed that the spectral irradiance $D N I_{P, A E R O N E T}$ stays stable between samples).

"This is the peer reviewed version of the following article: R. Núñez, C. Jin, M. Victoria, C. Domínguez, S. Askins, R. Herrero, I. Antón, and G. Sala, "Spectral study and classification of worldwide locations considering several multijunction solar cell. technologies: Spectral study and classification of worldwide locations," Prog. Photovolt: Res. Appl., 2016, which has been published in final form at http://onlinelibrary.wilev.com/doi/10.1002/pip.2781/full. This article may be used for non-commercial purposes in accordance with Wiley Terms and Conditions for Self-Archiving [http://olabout.wiley.com/WileyCDA/Section/id-820227.html\#terms]." 


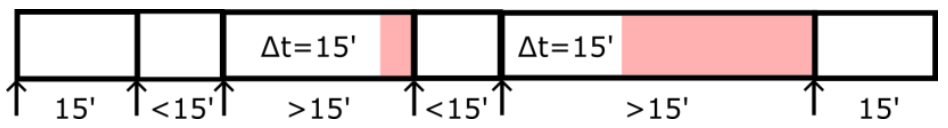

Figure 2 Schema of an example of sampling blocks from AERONET data series. Red areas indicate the time of sample that is considered not to have actual information

Since the time resolution is variable and calculated as the difference between two samples, any lack of data of the AERONET station caused by overcast, instrument failure or any other reason could be interpreted as longer periods with extra irradiation. As a result time intervals exceeding 15 minutes are constrained to 15 minutes, assuring that only actual measurements count to estimate the annually DNI-weighted SMRs; see Figure 2. For that reason the total considered energy per site in this study (from now on AERONET annual DNI) is going to be limited by AERONET availability. Although previous filters have constrained the set of sites to those with the highest amount of data, the total annual DNI measured by AERONET is going to be lower than if it was measured by a pyrheliometer.

Annually DNI-weighted average atmospheric parameters have been calculated using the same procedure. The results of these annually DNI-weighted average atmospheric parameters $(\overline{\mathrm{AM}}, \overline{\mathrm{AOD}}$, and $\overline{\mathrm{PW}})$ and annually DNI-weighted average SMR $\left(\overline{\mathrm{SMR}}_{\mathrm{mid}}^{\mathrm{top}}\right.$ and $\left.\overline{\mathrm{SMR}}_{\mathrm{bot}}^{\mathrm{mid}}\right)$ for all listed locations are detailed in the Appendix.

A graphical representation of the distribution of the annual DNI as a function of $\mathrm{SMR}_{\text {mid }}^{\text {top }}$ and $\mathrm{SMR}_{\mathrm{bot}}^{\text {mid }}$ has been proposed [35] for the spectral characterization of a particular site for CPV applications, whose coordinates $\overline{\mathrm{SMR}}_{\text {mid }}^{\mathrm{top}}$ and $\overline{\mathrm{SMR}}_{\mathrm{bot}}^{\mathrm{mid}}$ reveal how well matched is a particular MJ technology to that site and the current balance correction needed to optimize that technology to the site. While that work was based on long time spectral characterization of the site based on component cells, data that are available only in very few sites over the world, here we propose the use of the extended AERONET database to determine the potential solar resource for CPV applications.

\subsection{Experimental validation. Case study: Madrid}

IES-UPM has been collecting spectroheliometer SMR data since 2011 at a site that is only $200 \mathrm{~m}$ distant from an AERONET station maintained by the Spanish state meteorological agency (AEMET). Both instruments see virtually the same sky (when no clouds are present in the low-étage), which represents a convenient scenario for comparing both spectral data sources.

As an example of the aforementioned graphical representation, Figure 3 shows the spectral distribution of DNI in Madrid for the year 2013, obtained from the spectroheliometer and AERONET data processed with SMARTS. Considering that AERONET stations usually have a sampling frequency of 15 minutes and the spectroheliometer is sampled every minute, the spectroheliometer dataset has been interpolated to the time array of the AERONET data. Regarding data screening, AERONET level 2.0 data quality has been selected, therefore it assures cloud screening plus manual quality verification [36]. The false color map is an indication of the direct normal irradiation that is received in the site for every pair of SMR values. The coordinates $\overline{\mathrm{SMR}}_{\text {mid }}^{\mathrm{top}}$ and $\overline{\mathrm{SMR}}_{\mathrm{bot}}^{\mathrm{mid}}$ are respectively 0.94 and 1.00 obtained from the spectroheliometer measurements and 0.94 and 0.98 from the AERONET atmospheric data and simulated spectrally resolved DNI, which shows a good agreement between both procedures.

"This is the peer reviewed version of the following article: R. Núñez, C. Jin, M. Victoria, C. Domínguez, S. Askins, R. Herrero, I. Antón, and G. Sala, "Spectral study and classification of worldwide locations considering several multijunction solar cell technologies: Spectral study and classification of worldwide locations," Prog. Photovolt: Res. Appl., 2016, which has been published in final form at http://onlinelibrarv.wilev.com/doi/10.1002/pip.2781/full. This article may be used for non-commercial purposes in accordance with Wiley Terms and Conditions for Self-Archiving [http://olabout.wiley.com/WileyCDA/Section/id-820227. html\#terms]." 


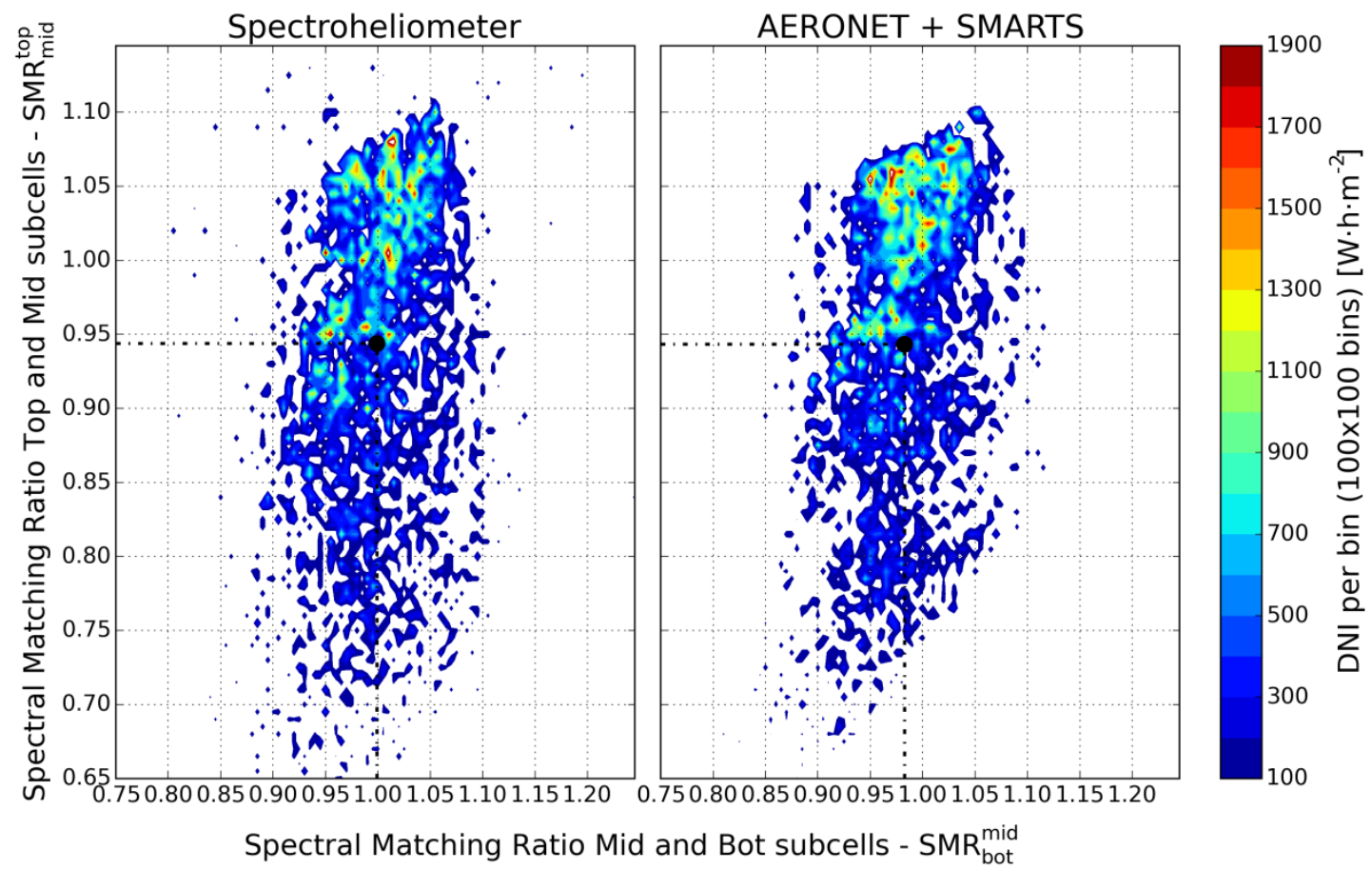

Figure 3 Spectral distribution of the direct normal irradiation in Madrid throughout 2013 expressed as a function of spectral matching ratios $\left(S M R_{\text {mid }}^{\text {top }}\right.$ and $\left.S M R_{\text {bot }}^{\text {mid }}\right)$. The black dot indicates the barycenter, i.e. the annual DNI-weighted mean SMR values. (Left) SMR and DNI determined from experimental measurements with spectroheliometer and pyrheliometer, respectively. (Right) SMR and DNI are integrated from a "synthetic" spectrum generated with SMARTS fed with AERONET data.

\section{MAPPING THE SOLAR RESOURCE WITH THE SPECTRAL CHARACTERISTICS OF WORLDWIDE LOCATIONS}

The aim of this section is to show the capability of a set of SMR indexes, namely two SMRs for the case of triple junction solar cells, to characterize a particular atmospheric condition for that MJ solar cell technology. Among the atmospheric parameters, air mass (AM) corrected with site elevation [37], aerosol optical depth (AOD), and precipitable water (PW) are considered to be the main factors impacting DNI spectrum, while others such as ambient temperature, air pressure, ozone and others have a minor impact [38]. Therefore, for the case of MJ cells, a particular atmospheric condition can be determined by means of the triplet (AM, AOD, PW). Nevertheless, the impact of such atmospheric condition on the MJ device performance cannot be directly calculated, but it is necessary to estimate the spectral distribution of DNI first by means of a radiative transfer model and then calculate the performance of the device through its spectral response. Alternatively, SMR indexes allow the direct estimation of the impact on the MJ performance since they account for the variations in current ratios among the subcells of the device. Thus, it would be helpful to determine relationships between the atmospheric indexes (AM, AOD, PW) and the spectral indexes (SMRs).

The selected sites (see Appendix for details), which cover a wide range of climatic conditions, will be used to determine the correlation between both atmospheric and SMR indexes. We shall start studying the atmospheric parameters that affects each SMR index, not only for the case of

"This is the peer reviewed version of the following article: R. Núñez, C. Jin, M. Victoria, C. Domínguez, S. Askins, R. Herrero, I. Antón, and G. Sala, "Spectral study and classification of worldwide locations considering several multijunction solar cell technologies: Spectral study and classification of worldwide locations," Prog. Photovolt: Res. Appl., 2016, which has been published in final form at http://onlinelibrary.wilev.com/doi/10.1002/pip.2781/full. This article may be used for non-commercial purposes in accordance with Wiley Terms and Conditions for Self-Archiving [http://olabout.wiley.com/WileyCDA/Section/id-820227. html\#terms]." 
instantaneous SMR values but also the annual DNI-weighted averages $\overline{\mathrm{SMR}}_{\text {mid }}^{\mathrm{top}}$ and $\overline{\mathrm{SMR}}_{\text {bot }}^{\text {mid }}$. For this second case, we shall use the annual DNI-weighted averages of the atmospheric parameters as input values, i.e. $\overline{\mathrm{AM}}, \overline{\mathrm{AOD}}$, and $\overline{\mathrm{PW}}$, instead of their instant values.

\subsection{Annually DNI-weighted top-middle SMR vs. geographic parameters}

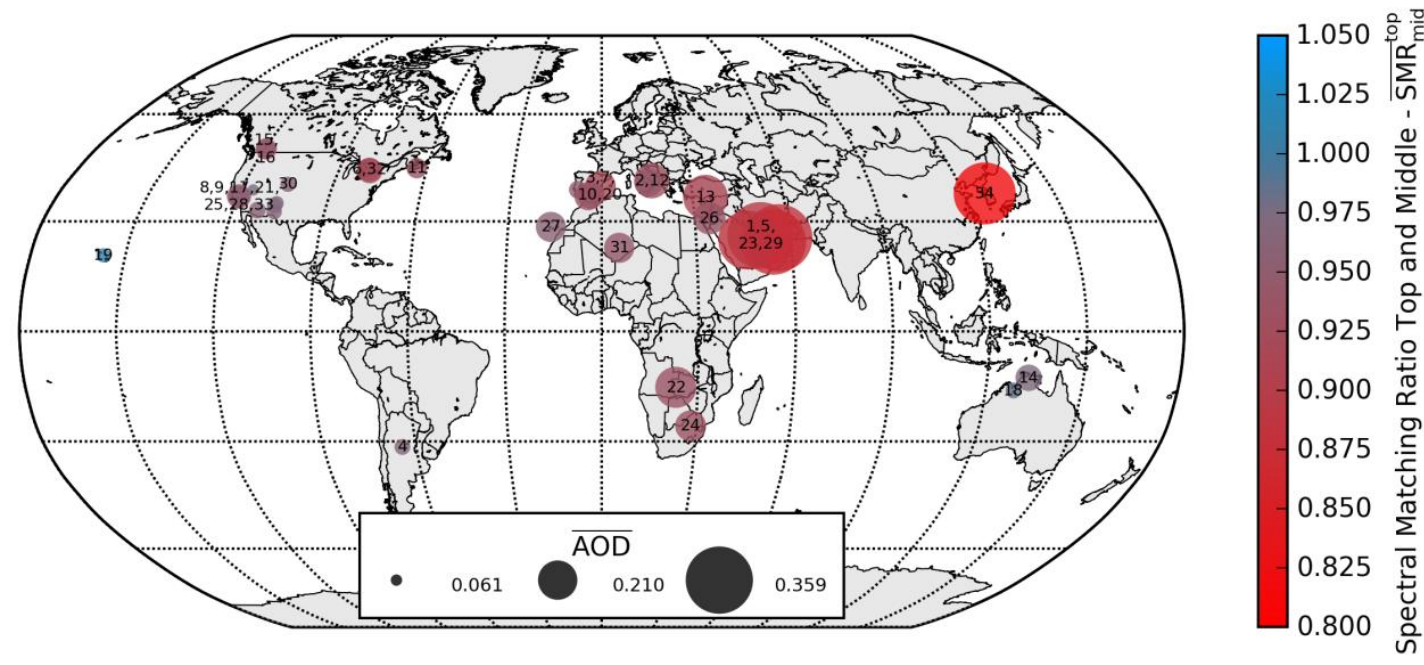

Figure 4 World distribution of selected AERONET locations showing both their annual DNI-weighted mean spectral matching ratio between top and middle subcells $\left(\overline{S M R}_{\text {mid }}^{\text {top }}\right)$ and their annual DNI-weighted mean aerosol optical depth $\overline{A O D} . \overline{S M R}_{\text {mid }}^{\text {top }}$ is represented in a color scale while a diameter scale is used for $\overline{A O D}$.

Note: numbers inside circles identify locations and can be found in Appendix.

The $\mathrm{SMR}_{\text {mid }}^{\text {top }}$ index covers the top and middle subcell spectral regions, i.e., from 350 to $900 \mathrm{~nm}$, so it is mainly affected by AM and AOD [27]. The lower the latitude, the lower the mean air mass, which result in higher values of $\overline{\mathrm{SMR}}_{\text {mid }}^{\text {top }}$. The 34 values of $\overline{\mathrm{SMR}}_{\text {mid }}^{\text {top }}$ for the studied sites are represented in a global map (Figure 4) as circles with a color scale together with the corresponding $\overline{\mathrm{AOD}}$ through the circle diameter, showing a clear relationship between both parameters. In general, low $\overline{\mathrm{AOD}}$ sites (small dots) show higher $\overline{\mathrm{SMR}}_{\text {mid }}^{\text {top }}$ values (blue dots) as Lanai in Hawaii (19) or Cordoba (4) in Argentina, while high $\overline{\mathrm{AOD}}$ sites (large dots) show low $\overline{\mathrm{SMR}}_{\text {mid }}^{\text {top }}$ values (red dots) as the Arabian Desert (1, 5, 23 and 29) or Yonsei-University (34) in Seoul (a polluted big city due to anthropogenic reasons [39]). A distinctive site is Tamanrasset (31) in Algeria, in the middle of the Sahara desert, which shows a low $\overline{\mathrm{AOD}}$ due to its particular local conditions such as a dry-cool season with low AOD [40], plus a relative high altitude $(1377 \mathrm{~m})$ that increases its $\overline{\mathrm{SMR}}_{\mathrm{mid}}^{\text {top }}$. Other notable examples related to altitude are in the North American South West, where several locations (25, 28, 30 and 33) have an altitude over $1200 \mathrm{~m}$ (see Appendix) leading to higher $\overline{\mathrm{AM}}$ values that added to lower $\overline{\mathrm{AOD}}$ than other sites of similar latitudes is reflected in higher levels of $\overline{\mathrm{SMR}}_{\text {mid }}^{\text {top }}$.

"This is the peer reviewed version of the following article: R. Núñez, C. Jin, M. Victoria, C. Domínguez, S. Askins, R. Herrero, I. Antón, and G. Sala, "Spectral study and classification of worldwide locations considering several multijunction solar cell technologies: Spectral study and classification of worldwide locations," Prog. Photovolt: Res. Appl., 2016, which has been published in final form at http://onlinelibrary.wilev.com/doi/10.1002/pip.2781/full. This article may be used for non-commercial purposes in accordance with Wiley Terms and Conditions for Self-Archiving [http://olabout.wiley.com/WileyCDA/Section/id-820227. htm/\#terms]." 


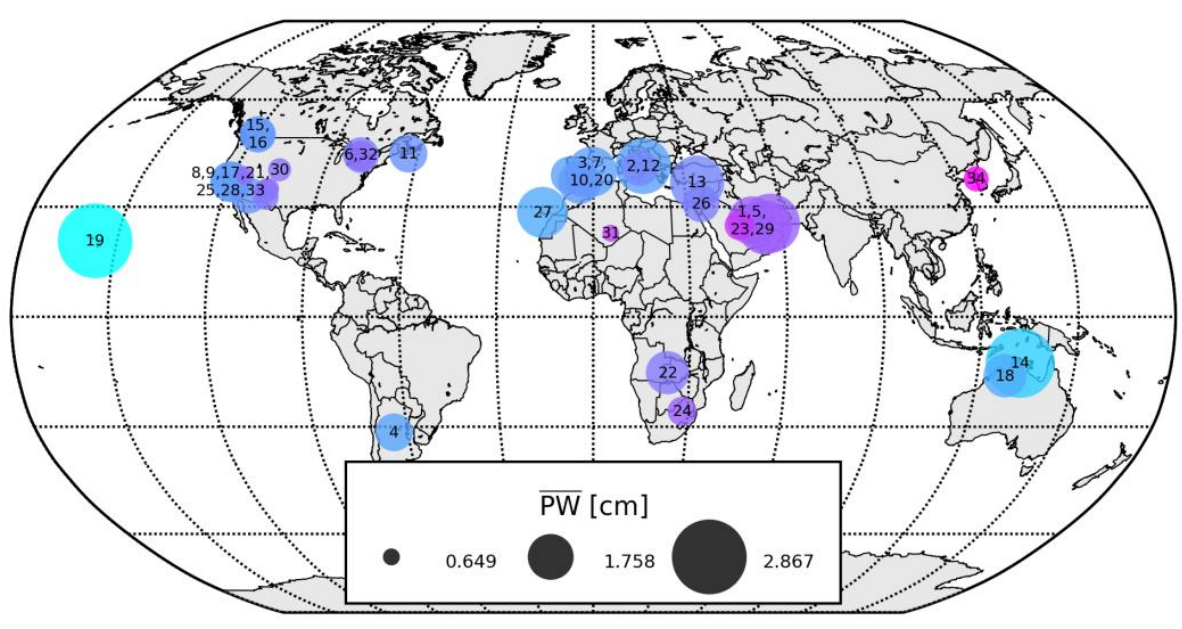

Figure 5 World distribution of selected AERONET locations showing both their annually DNI-weighted Spectral Matching Ratio between Middle and Bottom subcells $\left(\overline{S M R}_{\text {bot }}^{\text {mid }}\right)$ and their annually DNI-weighted Precipitable Water $(\overline{P W}) . \overline{S M R}_{\text {bot }}^{\text {mid }}$ is represented in a color scale while a diameter scale is used for $\overline{P W}$. Note: numbers inside circles identify locations and can be found in Appendix.

The relationship of $\overline{\mathrm{SMR}}_{\mathrm{bot}}^{\mathrm{mid}}$ with $\overline{\mathrm{PW}}$ is pointed out in Figure 5. The higher the $\overline{\mathrm{PW}}$, the stronger the absorption of the DNI in the infrared region, more important in the bottom subcell region than in the middle one, leading to high $\mathrm{SMR}_{\mathrm{bot}}^{\mathrm{mid}}$ values. Consequently, the proximity of big masses of water (as in the case of islands and coastal sites) increases the level of $\overline{\mathrm{SMR}}_{\mathrm{bot}}^{\mathrm{mid}}$; some example cases are Lanai (19) in Hawaii and Jabiru (14) and Lake Argyle (18) in Australia. On the other hand, especially dry sites, such as the North American South West $(25,28,30$ and 33) or in inner deserts show very low $\overline{\mathrm{SMR}}_{\mathrm{bot}}^{\mathrm{mid}}$, with Tamanrasset (31) [40] being a good example.

Again Yonsei-University (34) is an interesting special case that is worth noticing due to the influence of the East Asian monsoon in its climate with a humid summer and a dry winter [41]. Since precipitations are correlated with less irradiation, the annual DNI-weighted values of Seoul are prone to spectral conditions of winter, i.e. low PW and therefore low $\overline{\mathrm{SMR}}_{\mathrm{bot}}^{\mathrm{mid}}$, decreased even further by its high level of $\overline{\mathrm{AOD}}$.

\subsection{Relationship between spectral parameters and SMRs}

In a previous work [27], the relationships between the SMR indexes and atmospheric parameters were determined based on experimental instantaneous data measured in Madrid throughout the year 2013. This relationship can be obtained from a set of places that can be considered to be representative of the areas where $\mathrm{CPV}$ is prone to be installed among the selected sites from AERONET network, i.e. those whose $\overline{\mathrm{AOD}}$ is lower than 0.15 and $\overline{\mathrm{PW}}$ is between 0.7 and 2 . This group needs also to be filtered by the AERONET annual DNI, but as it was pointed out in paragraph 3.2, we cannot consider AERONET annual DNI as an absolute reference. Therefore, we take as threshold the median energy of

"This is the peer reviewed version of the following article: R. Núñez, C. Jin, M. Victoria, C. Dominguez, S. Askins, R. Herrero, I. Antón, and G. Sala, "Spectral study and classification of worldwide locations considering several multijunction solar cell technologies: Spectral study and classification of worldwide locations," Prog. Photovolt: Res. Appl., 2016, which has been published in final form at http://onlinelibrary.wilev.com/doi/10.1002/pip.2781/full. This article may be used for non-commercial purposes in accordance with Wiley Terms and Conditions for Self-Archiving [http://olabout.wiley.com/WileyCDA/Section/id-820227.html\#terms]." 
the group that drops sites that clearly are not target for CPV as Toronto (32), Halifax (11) or Egbert (6), all in Canada. In the end, 13 sites are selected as base for the model whose names are highlighted in bold in Table 2 and Table 3 of the Appendix.

The proposed model is linear plus some products that account for parameters that affect similar spectral regions:

$$
\begin{gathered}
\mathrm{SMR}_{\text {mid }}^{\mathrm{top}}=1.14-0.09 \cdot A M-0.19 \cdot A O D+0.02\left[\mathrm{~cm}^{-1}\right] \cdot P W-0.15 \cdot A M \cdot A O D \\
\mathrm{SMR}_{\mathrm{bot}}^{\mathrm{mid}}=0.92-0.30 \cdot A O D+0.07\left[\mathrm{~cm}^{-1}\right] \cdot P W-0.06\left[\mathrm{~cm}^{-1}\right] \cdot A O D \cdot P W
\end{gathered}
$$

This instantaneous SMR model is applied to all sites, including those who were not selected to create the model. The accuracy of the model for each location can be evaluated looking at the residuals that should be approximately normally distributed, where a low standard distribution shows a good fitting and a zero centered distribution stands for an unbiased estimation. In Figure 6 mean value and standard deviation (in percentage) of residuals are plotted for each location. Outliers, defined here as those moments of every location whose residuals are larger than 0.1 , were filtered out (they represent less than $1 \%$ of the total of the moments). The figure shows a better fitting for the 13 selected sites (round dots), while other climates with lower potential for CPV show higher dispersion and bias in the residuals, taking into account always that the model is an approximation of several non-linear effects. Even for climates with very high AOD values not suited for CPV installations, such as Bahrain (1) or and Yonsei-University (34) in Seoul, the model works reasonably well and is able to show the strong correlation between SMR indexes and atmospheric parameters.

"This is the peer reviewed version of the following article: R. Núñez, C. Jin, M. Victoria, C. Domínguez, S. Askins, R. Herrero, I. Antón, and G. Sala, "Spectral study and classification of worldwide locations considering several multijunction solar cell technologies: Spectral study and classification of worldwide locations," Prog. Photovolt: Res. Appl., 2016, which has been published in final form at http://onlinelibrary.wilev.com/doi/10.1002/pip.2781/full. This article may be used for non-commercial purposes in accordance with Wiley Terms and Conditions for Self-Archiving 


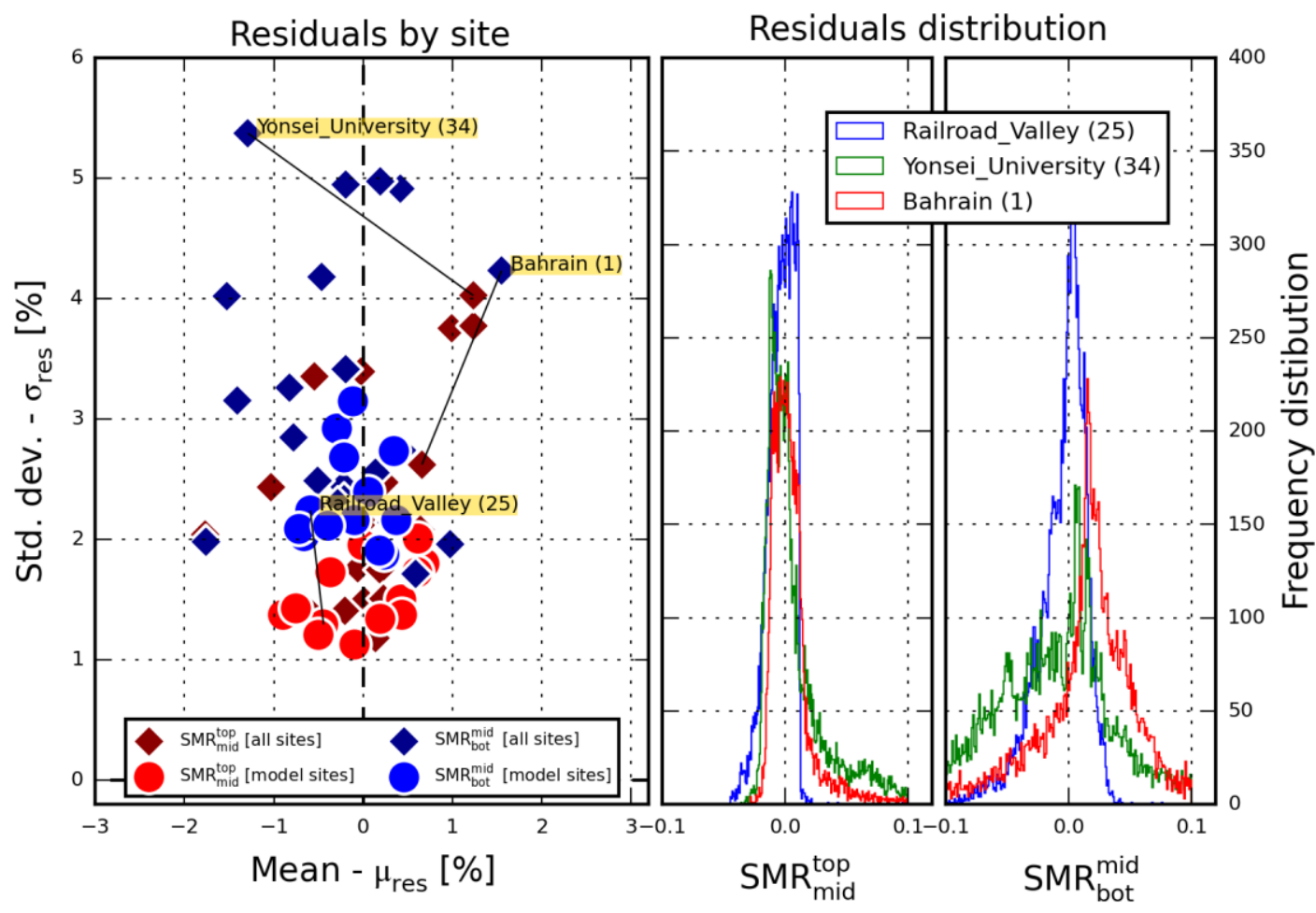

Figure 6 (Left) Mean and standard deviation of residuals of the 34 sites selected from AERONET applying the model proposed in Eqs. (4) and (5) that relates atmospheric parameters (air mass, aerosols and precipitable water) and spectral matching ratios (SMR mid and $S M R_{\text {bot }}^{\text {mid }}$ ). (Right) Detail of residuals distributions of a CPV site selected in model (Railroad_Valley (25) ) and two outlier sites (Yonsey_University (34) and Bahrain (1)).

As stated above, the $\overline{\mathrm{SMR}}_{\text {mid }}^{\mathrm{top}}$ and $\overline{\mathrm{SMR}}_{\mathrm{bot}}^{\text {mid }}$ are the spectral coordinates that reveal how well matched is a particular MJ technology to the spectral conditions of a site. In this sense, the relationship between the local annually DNI-weighted average atmospheric parameters to such coordinates would provide a fast way to determine the potential of a particular site for a particular MJ technology. Similar equations to the instantaneous model are revealed but with slightly different coefficients, as is shown in Eqs. (6) and (7). Again, only the $13 \mathrm{CPV}$-prone sites have been used to determine this time the fit parameters of an annual model. This model is based on annual DNI-weighted averages of the atmospheric parameters as input values, i.e. $\overline{\mathrm{AM}}, \overline{\mathrm{AOD}}$, and $\overline{\mathrm{PW}}$, instead of their corresponding instant values:

$$
\begin{gathered}
\overline{\mathrm{SMR}}_{\text {mid }}^{\mathrm{top}}=1.14-0.10 \cdot \overline{A M}-0.43 \cdot \overline{A O D}+0.03 \cdot \overline{P W}-0.19 \cdot \overline{A M} \cdot \overline{A O D} \\
\overline{\mathrm{SMR}}_{\mathrm{bot}}^{\mathrm{mid}}=0.91-0.34 \cdot \overline{A O D}+0.07 \cdot \overline{P W}+0.25 \cdot \overline{A O D} \cdot \overline{P W}
\end{gathered}
$$

Even though $\overline{\mathrm{PW}}$ has been included in the Eq. (6), its influence in $\overline{\mathrm{SMR}}_{\text {mid }}^{\text {top }}$ is less than $3 \%$, so from here on it will be neglected in the graph (but not in the model) to ease the graphical representation of the involved spectral parameters.

"This is the peer reviewed version of the following article: R. Núñez, C. Jin, M. Victoria, C. Domínguez, S. Askins, R. Herrero, I. Antón, and G. Sala, "Spectral study and classification of worldwide locations considering several multijunction solar cell fechnologies: Spectral study and classification of worldwide locations," Prog. Photovolt: Res. Appl., 2016, which has been published in final form at http://onlinelibrary.wilev.com/doi/10.1002/pip.2781/full. This article may be used for non-commercial purposes in accordance with Wiley Terms and Conditions for Self-Archiving [http://olabout.wiley.com/WileyCDA/Section/id-820227. html\#terms]." 
In Figure 7, the annual DNI-weighted average $\overline{\mathrm{SMR}}_{\text {mid }}^{\text {top }}$ for the 34 selected locations using AERONET network are represented as a function of $\overline{\mathrm{AM}}$ and $\overline{\mathrm{AOD}}$. The black dashed lines represent simplified Eq. (6) for a constant $\overline{\mathrm{PW}}$ value (mean annual value for model sites: $1.28 \mathrm{~cm}$ ). Accordingly, dots of the same color should be superimposed onto their corresponding black dashed line.

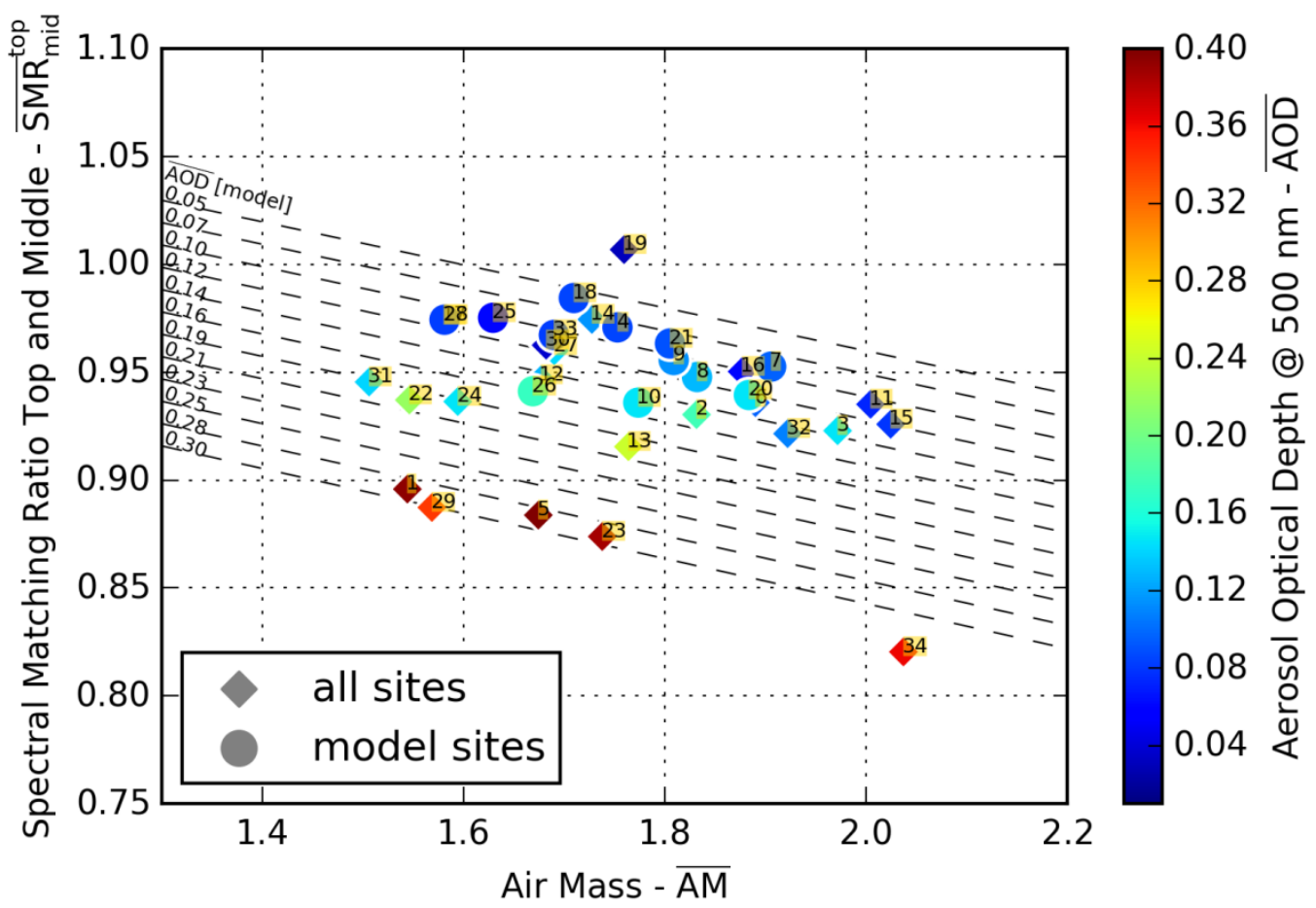

Figure 7 Spectral Matching Ratio between top and middle subcells ( $\overline{\mathbf{S M R}}_{\mathrm{mid}}^{\text {top }}$ ) versus atmospheric parameters of the annual DNI-weighted averages of the 34 selected locations around the world using AERONET network.

To ease the representation, only the two main factors are considered (Air Mass $\overline{\mathrm{AM}}$ and Aerosol Optical Depth $\overline{\mathrm{AOD}}$ ). Black dashed lines represent the fitting model. Note: numbers inside circles identify locations and can be found in Appendix.

The figure shows a clear relationship between the values of $\overline{\mathrm{SMR}}_{\text {mid }}^{\mathrm{top}}$ and $\overline{\mathrm{AM}}$ and $\overline{\mathrm{AOD}}$, the higher the $\overline{\mathrm{AM}}$ and $\overline{\mathrm{AOD}}$, the lower the level of $\overline{\mathrm{SMR}}_{\text {mid }}^{\mathrm{top}}$. Residuals considering the full model of Eq. (6) are normally distributed and the standard error of estimate is $0.55 \%$. Error increases to $1.28 \%$ if $\overline{\mathrm{PW}}$ is neglected and decreases to $0.12 \%$ when the model is applied only to the 13 sites used to build the model.

A similar analysis can be carried out considering $\overline{\mathrm{SMR}}_{\mathrm{bot}}^{\mathrm{mid}}$ and the atmospheric parameters that mainly affect it, namely $\overline{\mathrm{PW}}$ and $\overline{\mathrm{AOD}}$. In Figure $8, \overline{\mathrm{SMR}}_{\mathrm{bot}}^{\mathrm{mid}}$ versus $\overline{\mathrm{PW}}$ and $\overline{\mathrm{AOD}}$ is plotted for the 34 sites, as well as the fitting model in black dashed lines.

"This is the peer reviewed version of the following article: R. Núñez, C. Jin, M. Victoria, C. Domínguez, S. Askins, R. Herrero, I. Antón, and G. Sala, "Spectral study and classification of worldwide locations considering several multijunction solar cell technologies: Spectral study and classification of worldwide locations," Prog. Photovolt: Res. Appl., 2016, which has been published in final form at http://onlinelibrary.wilev.com/doi/10.1002/pip.2781/full. This article may be used for non-commercial purposes in accordance with Wiley Terms and Conditions for Self-Archiving [http://olabout.wiley.com/WileyCDA/Section/id-820227.html/\#terms]." 


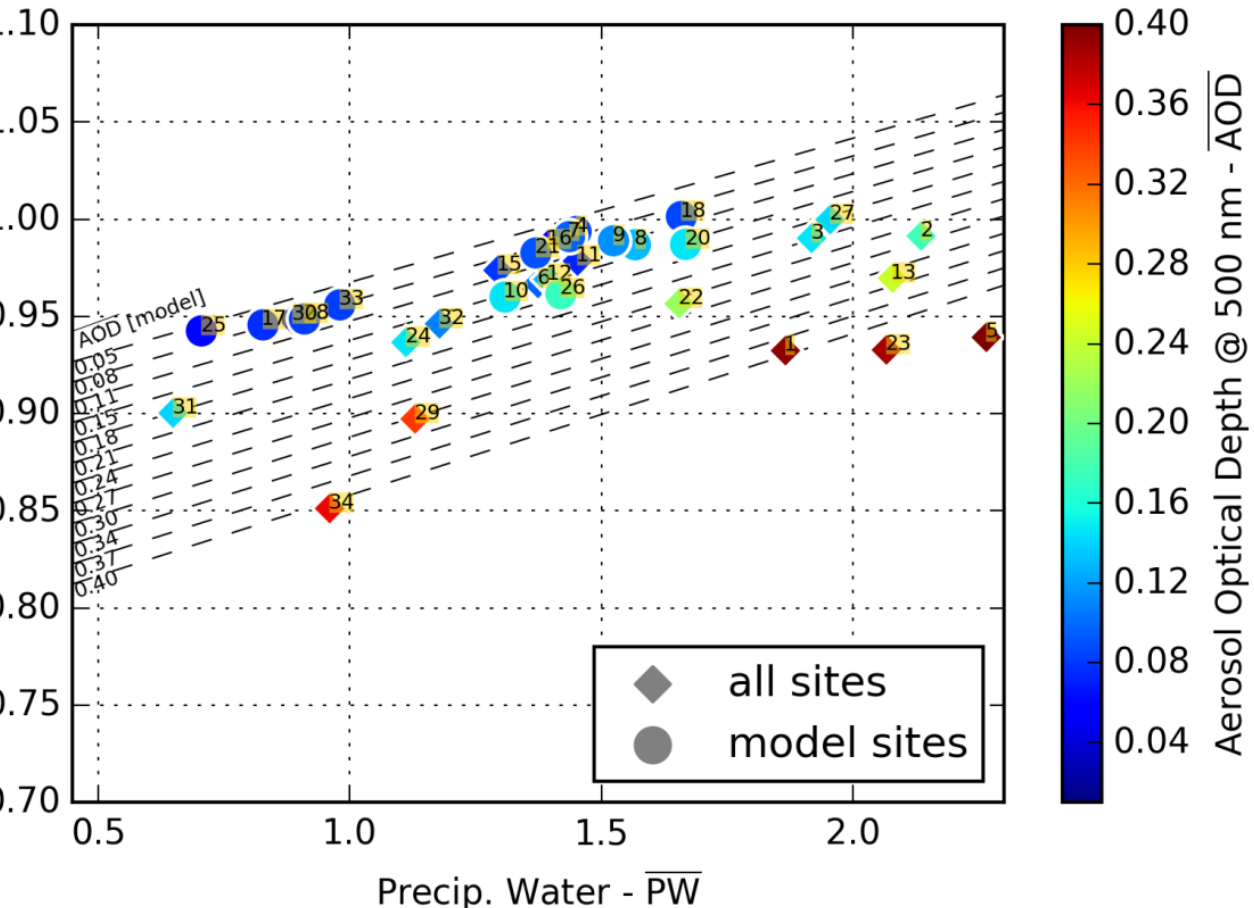

Figure 8 Spectral matching ratios between middle and bottom subcells $\left(\overline{\mathbf{S M R}}_{\text {bot }}^{\text {mid }}\right)$ versus relevant spectral parameters ( $\overline{\mathbf{P W}}$ and $\overline{\mathbf{A O D}})$. Black dashed lines represent the fitting model. Annual DNI-weighted averages of the $\mathbf{3 4}$ selected locations around the world using AERONET network. Note: numbers inside circles identify locations and can be found in Appendix.

As in the previous case, there is a high correlation between $\overline{\mathrm{SMR}}_{\mathrm{bot}}^{\text {mid }}$ and the atmospheric parameters with a standard error of estimate of $1.20 \%$ for the 34 sites and $0.23 \%$ for the 13 sites that feed the model. Furthermore, it is interesting to notice that for the spectral ranges of the QE of LM-Ge 3J cell technology, air mass does not significantly contribute to $\overline{\mathrm{SMR}}_{\mathrm{bot}}^{\mathrm{mid}}$, and consequently it was ignored in Eq. (7).

\section{GLOBAL ANALYSIS OF SPECTRAL INFLUENCE FOR SEVERAL KINDS OF TRIPLE JUNCTION CELLS}

The analyses in previous sections were conducted on $\mathrm{LM} \mathrm{GaInP/GaInAs/Ge} \mathrm{triple} \mathrm{junction} \mathrm{solar}$ cells, hereafter LM-Ge. The aim of this section is to compare these data with those obtained for other triple junction technologies, including various types of lattice-matched and metamorphic triple-junction solar cells. Table 1 shows the materials and bandgaps of the cells used in the study, covering on the one hand lattice-matched 3J solar cells, both traditional cells based on Ge substrates and cells based on dilute nitrides, and on the other hand metamorphic $3 \mathrm{~J}$ solar cells, both upright and inverted grown.

Table 1 Description of the four cell technologies considered in this work

\begin{tabular}{|l|l|l|l|}
\hline Cell technology & Layers & BandGaps & Ref. \\
\hline Lattice matched germanium & InGaP/InGaAs/Ge & $1.88 / 1.4 / 0.67 \mathrm{eV}$ & $\mathrm{LM}-\mathrm{Ge}$ \\
\hline
\end{tabular}

"This is the peer reviewed version of the following article: R. Núnez, C. Jin, M. Victoria, C. Domínguez, S. Askins, R. Herrero, I Antón, and G. Sala, "Spectral study and classification of worldwide locations considering several multijunction solar cell technologies: Spectral study and classification of worldwide locations," Prog. Photovolt: Res. Appl., 2016, which has been published in final form at http://onlinelibrary.wilev.com/doi/10.1002/pip.2781/full. This article may be used for non-commercial purposes in accordance with Wiley Terms and Conditions for Self-Archiving [http://olabout.wiley.com/WileyCDA/Section/id-820227.html\#terms]." 


\begin{tabular}{|l|l|l|l|}
\hline Upright Metamorphic & InGaP/InGaAs/Ge & $1.82 / 1.33 / 0.67 \mathrm{eV}$ & UMM \\
\hline Inverted Metamorphic & InGaP/GaAs/InGaAs & $1.89 / 1.41 / 1.0 \mathrm{eV}$ & $\mathrm{IMM}$ \\
\hline Lattice matched dilute nitride & InGaP/GaAs/InGaAsNSb & $1.89 / 1.41 / 1.0 \mathrm{eV}$ & LM-DN \\
\hline
\end{tabular}

The same calculation detailed in sections 3 and 4 has been carried out for the other three types of solar cells (UMM, IMM and LM-DN). An entire year of AERONET data obtained for the 34 sites is used for the simulation, by means of SMARTS, of the spectrally resolved DNI. Then, for the four MJ technologies of the table, the photocurrents of the three subcells and the corresponding instantaneous values of $\mathrm{SMR}_{\mathrm{bot}}^{\text {top }}$ and $\mathrm{SMR}_{\mathrm{bot}}^{\mathrm{mid}}$ are calculated for each location over the course of the year with the time resolution of the AERONET data $(15 \mathrm{~min})$. Finally, the annually DNI-weighted values of $\overline{\mathrm{SMR}}_{\text {mid }}^{\text {top }}$ and $\overline{\mathrm{SMR}}_{\mathrm{bot}}^{\mathrm{mid}}$ are calculated and compared. Numeric results are listed in the Table 3 of the Appendix and graphical comparisons are shown in Figure 9.

Figure 9 shows $\overline{\mathrm{SMR}}_{\text {mid }}^{\text {top }}$ and $\overline{\mathrm{SMR}}_{\text {bot }}^{\text {mid }}$ for the four cell technologies. The differences between the cell technologies is observed to be relatively low compared to the strong differences between locations, which is a consequence of the high degree of similarity between the spectral range of top, middle and bottom subcells for the four technologies. Some sites have geographic parameters in common and form clusters that have similar levels of annual DNI-weighted spectral parameters relevant to highlight as those in deserts, close to big masses of water and North-American South-West.

Regarding $\overline{\mathrm{SMR}}_{\mathrm{mid}}^{\mathrm{top}}$ the differences among the technologies are below $1 \%$ for half of the sites and between $1 \%$ and $2 \%$ for the other half, while the values for the bunch of sites ranges about $20 \%$, from 0.82 to 1.03 . A second conclusion is that $\overline{\mathrm{SMR}}_{\text {mid }}^{\text {top }}$ are below one for most of the locations, which means that the average spectral irradiance is red-shifted, i.e., the bare cells would work under top current limitation on average (the spectral influence of the optics is not considered here). This apparent mismatch between annual DNI-weighted $\operatorname{SMR}_{\text {mid }}^{\text {top }}\left(\overline{\mathrm{SMR}}_{\text {mid }}^{\text {top }}<1\right)$ and spectral reference $\left(\mathrm{SMR}_{\mathrm{mid}}^{\text {top }}=1\right)$ is explained by the fact that the total integrated irradiance of the AM1.5D-G173 spectrum was chosen to match standard reporting condition irradiance [34] $\left(900 \mathrm{~W} \cdot \mathrm{m}^{-2}\right.$, typical at midday) and with very concrete atmospheric parameters, i.e. AOD (0.084) and PW $(1.42 \mathrm{~cm})$. Therefore while the spectral reference is representative usually of midday clear-sky conditions, DNI distribution over the year is mainly below the standard value. Consequently the main reason for this mismatch is that DNI during sunrise and sunset, even if they don't contribute as much as the values at midday, on average push down the $\overline{\mathrm{SMR}}_{\text {mid }}^{\text {top }}$.

The results suggest that the CPV module optimization should increase top current for the four technologies and most of the sites, which can be made at the cell level or by means of the optics, as for example promoting short wavelength focusing or tuning the antireflective coating [42]. The optimum top/mid current ratio under the reference spectrum must accomplish the following condition [9] for a particular site.

$$
\left.\overline{\mathrm{SMR}}_{\text {mid }}^{\text {top }} \cdot \mathrm{I}_{\text {ratio }}^{\text {top }}\right|_{A M 1.5 D-G 173}=1
$$


where $\quad$ I top stands for the top/mid current ratio at the reference spectrum

AM1.5D-G173. Depending on the purpose, this ratio can be considered only for the bare cells or including also the spectral transmission of the optics. In a further step, if the detailed spectral performance of the optics is known, including temperature dependence, it could be also included to calculate $\overline{\mathrm{SMR}}_{\text {mid }}^{\text {top }}$.

Bare cells are commonly optimized to have top/mid current ratio as close as possible to one under the reference spectrum, so the optics should inversely compensate $\overline{\mathrm{SMR}}_{\text {mid }}^{\mathrm{top}}$. It must be pointed out that many CPV optics transmits better in the middle range than in the top which worsen even more the top/mid current ratio, so this approach is not always possible. Alternatively the cell itself can be optimized according to the $\overline{\mathrm{SMR}}_{\text {mid }}^{\text {top }}$ value of the site and considering the spectral effect of the optics.

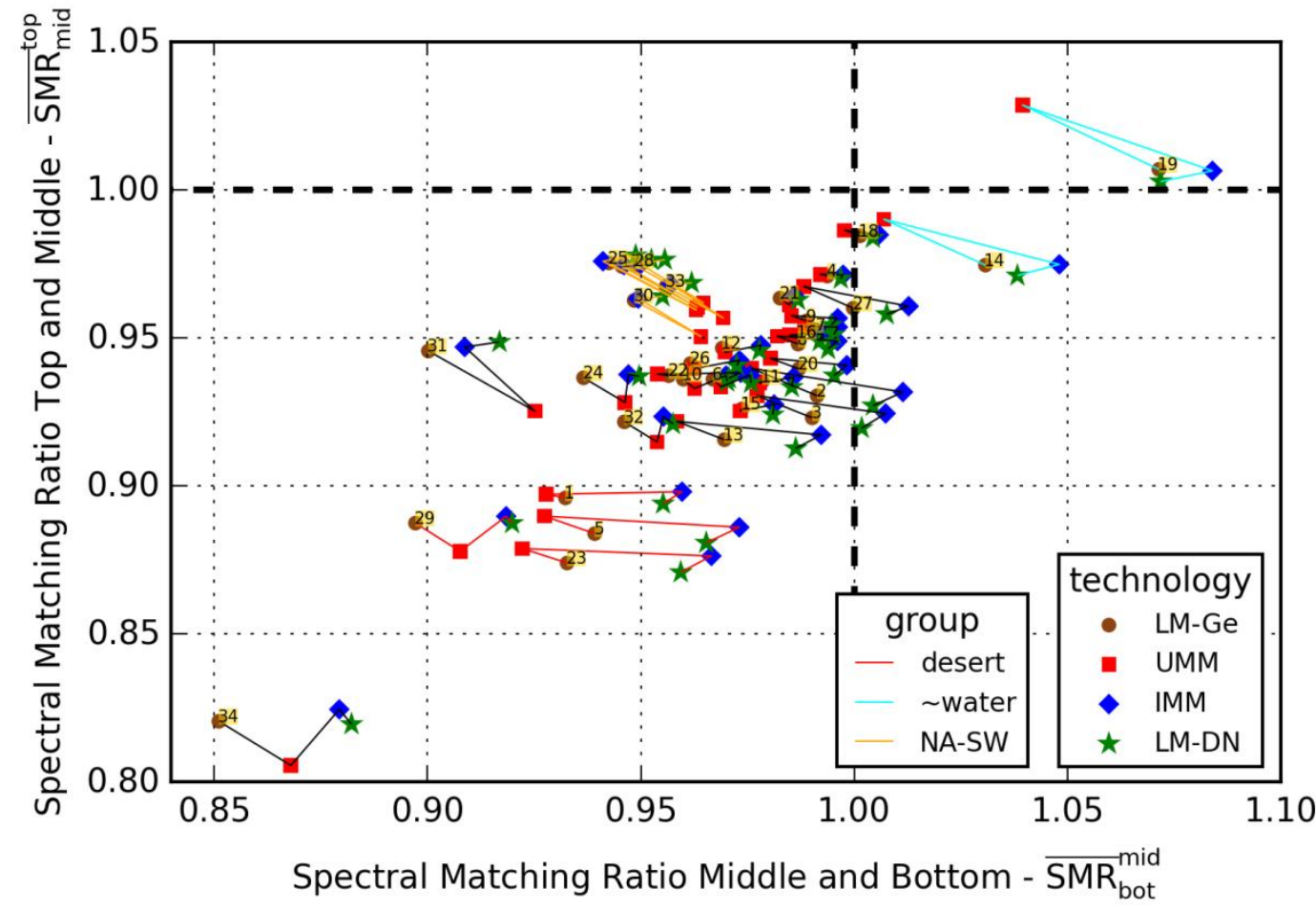

Figure 9 Annually DNI-weighted Spectral Matching Ratio between top and middle subcells $\left(\overline{S M R}_{\text {mid }}^{\text {top }}\right)$ and between middle and bottom subcells $\left(\overline{S M R}_{\text {bot }}^{\text {mid }}\right)$ for the selected locations considering four different $\mathrm{MJ}$ technologies: Lattice matched based on Germanium (LM-Ge), Upright Metamorphic (UMM), Inverted Metamorphic (IMM) and Lattice matched dilute nitride (LM-DN). Some sites have geographic parameters in common and form groups that have similar levels of annual DNI-weighted spectral parameters relevant to highlight as those in deserts (desert), close to big masses of water ( $\sim$ water) and North-American South-West

(NA-SW). Note: numbers inside circles identify locations and can be found in Appendix.

In a similar way, Figure 9 also shows $\overline{\mathrm{SMR}}_{\mathrm{bot}}^{\mathrm{mid}}$ for the 34 sites in the horizontal axis. In this case the differences among the 4 cell technologies are higher which correspond with the greater differences in the spectral responses of the 4 bottom subcells. About $60 \%$ of the sites show differences below $2 \%$,

"This is the peer reviewed version of the following article: R. Núñez, C. Jin, M. Victoria, C. Domínguez, S. Askins, R. Herrero, I. Antón, and G. Sala, "Spectral study and classification of worldwide locations considering several multijunction solar cell technologies: Spectral study and classification of worldwide locations," Prog. Photovolt: Res. Appl., 2016, which has been published in final form at http://onlinelibrary.wilev.com/doi/10.1002/pip.2781/full. This article may be used for non-commercial purposes in accordance with Wiley Terms and Conditions for Self-Archiving [http://olabout.wiley.com/WileyCDA/Section/id-820227.htmlitterms]." 
while the others have values up to $4.5 \%$. Nevertheless the differences among sites are again much higher and vary more than $20 \%$.

A majority of sites show also a $\overline{\mathrm{SMR}}_{\mathrm{bot}}^{\mathrm{mid}}$ value below one but in this case there are many sites with values close to one or above too. Nevertheless, the impact of the $\overline{\mathrm{SMR}}_{\mathrm{bot}}^{\text {mid }}$ depends very much on the cell technology, since the current of the bottom subcells exceeds the other two from only about $7 \%$ for the case of the LM-DN cells to more than $40 \%$ for the LM-Ge subcells. For this last technology, in any single location the bottom subcell will not limit the current of the device, but this may not be the case for the other technologies in specific sites.

It is worth making the point that the distance among SMR coordinates of different technologies of a given site is related to the closeness of its atmosphere to AM1.5D-G173 conditions. The closer is a location to the ideal situation $\left(\overline{\mathrm{SMR}}_{\mathrm{mid}}^{\mathrm{top}}=1\right.$ and $\left.\overline{\mathrm{SMR}}_{\mathrm{bot}}^{\mathrm{mid}}=1\right)$, the closer are the four SMR coordinates. Sites with high/low $\overline{\mathrm{AOD}} / \overline{\mathrm{PW}}$ as Yonsey_University (34) ( $\overline{\mathrm{AOD}}=0.33, \overline{\mathrm{PW}}=0.96)$ and low/high $\overline{\mathrm{AOD}} / \overline{\mathrm{PW}}$ as Lanai (19) $(\overline{\mathrm{AOD}}=0.08, \overline{\mathrm{PW}}=2.87)$ highlight those differences which are caused by the combination of the cut-off wavelengths of the subcells and the dominant levels of atmospheric components of a site.

\subsection{Spectral thermal drift}

The cell temperature impacts on the spectral response of MJ solar cells [43] and therefore on their current subcells and related SMR values. As it was pointed above, all the previous analyses considered a cell temperature of $90{ }^{\circ} \mathrm{C}$, closer to operation temperatures of MJ solar cells in a CPV module. QE of a solar cell tend to expand due to temperature, so depending on the cut-off levels of each subcell with respect solar spectrum, thermal changes can lead to different evolutions depending on the technology. Figure 10 shows the spectral coordinates for the four technologies at $25{ }^{\circ} \mathrm{C}$ and $90{ }^{\circ} \mathrm{C}$ revealing that most of thermal drifts are below 0.01 in both $\overline{\mathrm{SMR}}$ dimensions. Data for both temperatures for the four technologies are collected in Table 3 of the Appendix. 


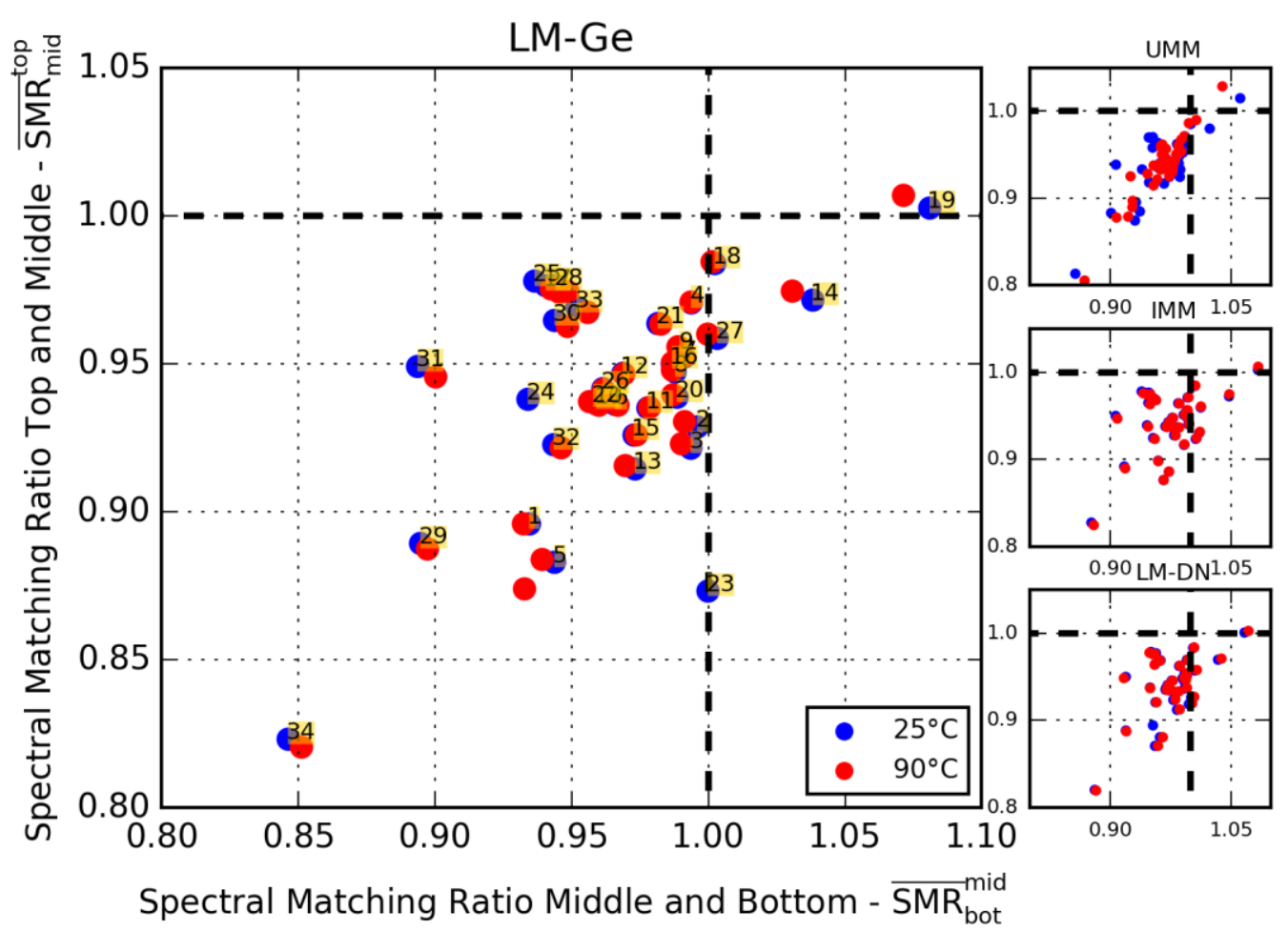

Figure 10 Annually DNI-weighted Spectral Matching Ratio between Top and Middle subcells $\left(\overline{S M R}_{\text {mid }}^{\text {top }}\right)$ and between Middle and Bottom subcells $\left(\overline{S M R}_{\text {bot }}^{\text {mid }}\right)$ for the selected locations at $25^{\circ} \mathrm{C}$ and $90^{\circ} \mathrm{C}$ considering four different MJ technologies: Lattice matched based on Germanium (LM-Ge), Upright Metamorphic (UMM), Inverted Metamorphic (IMM) and Lattice matched dilute nitride (LM-DN). Note: numbers inside circles identify locations and can be found in Appendix.

While the change due to temperature is negligible in IMM and LM-DN, the most sensitive technology is UMM, where in some extreme cases as Lanai (19) the thermal drift is almost 0.02. This is explained by the fact that the cut-off wavelengths of middle and bottom subcells are exactly at the first main waster-absorption peak of terrestrial solar spectrum around $940 \mathrm{~nm}$. The abrupt change of irradiance in this spectral area makes this technology more sensitive than the others to QE changes and so on to temperature.

\section{CONCLUSIONS}

Several capabilities of the SMR as spectral index for CPV applications have been shown in this paper beyond their most common use in the CPV community, which is filtering of operating conditions to fix a certain spectral condition. First, SMR indexes have been used to characterize the solar resource at a specific site through their annual DNI-weighted average values related to a MJ solar cell technology. This provides the spectral information that gives most of the necessary information for optimizing the spectral response of a CPV module (whose response at a reference site is known) for a new location. This may be carried out by tuning the current ratio of the receiver multi-junction cells by a factor corresponding to the difference in SMR between the known site and the new site or considering external factors as optics.

"This is the peer reviewed version of the following article: R. Núñez, C. Jin, M. Victoria, C. Domínguez, S. Askins, R. Herrero, I. Antón, and G. Sala, "Spectral study and classification of worldwide locations considering several multijunction solar cell technologies: Spectral study and classification of worldwide locations," Prog. Photovolt: Res. Appl., 2016, which has been published in final form at http://onlinelibrary.wilev.com/doi/10.1002/pip.2781/full. This article may be used for non-commercial purposes in accordance with Wiley Terms and Conditions for Self-Archiving [http://olabout.wiley.com/WileyCDA/Section/id-820227.html\#terms]." 
Then, the relationships between SMR indexes and atmosphere parameters, mainly AM, AOD, and PW have been determined not only for instantaneous values, but also for annual DNI-weighted averages, which allows the prediction of the SMR indexes if some geographic and atmosphere parameters of a site are known. The capability of the AERONET network to provide such needed parameters has been exploited in this study, selecting 34 worldwide sites with the best data quality and covering many different climate conditions.

Finally, the site characterization by means of SMR indexes have been extended to several triple-junction technologies, covering lattice-matched cells based on germanium and dilute nitrides and both inverted and upright metamorphic cells. The comparative analysis shows large differences in the performance of the devices between the selected locations, while the differences among the technologies were much less significant. Impact of solar cells temperature has been shown to be negligible in this analysis.

\section{ACKNOWLEDGEMENTS}

We thank the AERONET network and in particular the principal investigators and their staff for establishing and maintaining the 35 sites used in this investigation. This work has been supported by the Comunidad de Madrid through the program MADRID-PV-CM (S2013/MAE2780). Rubén Núñez is thankful to the Spanish Ministerio de Economía y Competitividad for his FPI grant. This work made use of the Scipy stack [44], an open-source Python-based scientific computing environment.

\section{APPENDIX}

Table 2 lists the 34 AERONET stations selected in this work, including geographic data, AERONET annual DNI and annual DNI-weighted spectral parameters for each location. Table 3 gives the annual DNI-weighted SMR indexes of the same list of locations for the different considered technologies at solar cell temperature of $25{ }^{\circ} \mathrm{C}$ and $90{ }^{\circ} \mathrm{C}$.

"This is the peer reviewed version of the following article: R. Núñez, C. Jin, M. Victoria, C. Domínguez, S. Askins, R. Herrero, I. Antón, and G. Sala, "Spectral study and classification of worldwide locations considering several multijunction solar cell technologies: Spectral study and classification of worldwide locations," Prog. Photovolt: Res. Appl., 2016, which has been published in final form at http://onlinelibrary.wilev.com/doi/10.1002/pip.2781/full. This article may be used for non-commercial purposes in accordance with Wiley Terms and Conditions for Self-Archiving 
Table 2 List of the 34 AERONET stations selected in this work, including geographic data, AERONET annual DNI and annual DNI-weighted spectral parameters. Sites highlighted in bold are those used in the model in paragraph 4.3.

\begin{tabular}{|c|c|c|c|c|c|c|c|c|}
\hline No & Location & Latitude $\left[{ }^{\circ}\right]$ & Longitude $\left[{ }^{\circ}\right]$ & Altitude [m] & AERONET annual DNI [kWh] & $\overline{\mathrm{AM}}$ & $\overline{\mathrm{AOD}}$ & $\overline{\mathrm{PW}}[\mathrm{cm}]$ \\
\hline 1 & Bahrain & 26.21 & 50.61 & 25.00 & 1318 & 1.54 & 0.35 & 1.87 \\
\hline 2 & Bari_University & 41.11 & 16.88 & 12.00 & 1539 & 1.83 & 0.19 & 2.13 \\
\hline 4 & Cordoba-CETT & -31.52 & -64.46 & 730.00 & 1548 & 1.75 & 0.09 & 1.45 \\
\hline 5 & Dhadnah & 25.51 & 56.33 & 81.00 & 1368 & 1.67 & 0.36 & 2.26 \\
\hline 6 & Egbert & 44.23 & -79.75 & 264.00 & 960 & 1.89 & 0.13 & 1.37 \\
\hline 7 & Evora & 38.57 & -7.91 & 293.00 & 1549 & 1.91 & 0.10 & 1.44 \\
\hline 8 & Fresno & 36.78 & -119.77 & 0.00 & 1798 & 1.83 & 0.13 & 1.57 \\
\hline 9 & Fresno_2 & 36.79 & -119.77 & 100.00 & 1735 & 1.81 & 0.12 & 1.52 \\
\hline 10 & Granada & 37.16 & -3.61 & 680.00 & 1576 & 1.77 & 0.15 & 1.31 \\
\hline 11 & Halifax & 44.64 & -63.59 & 65.00 & 996 & 2.00 & 0.11 & 1.45 \\
\hline 12 & IMAA_Potenza & 40.60 & 15.72 & 820.00 & 1209 & 1.68 & 0.15 & 1.39 \\
\hline 14 & Jabiru & -12.66 & 132.89 & 30.00 & 1430 & 1.73 & 0.14 & 2.66 \\
\hline 15 & Kelowna & 49.96 & -119.37 & 344.00 & 1047 & 2.02 & 0.11 & 1.29 \\
\hline 16 & Kelowna_UAS & 49.94 & -119.40 & 456.00 & 1002 & 1.88 & 0.10 & 1.39 \\
\hline 17 & Kirtland_AFB & 34.95 & -106.51 & 1711.00 & 2035 & 1.58 & 0.08 & 0.83 \\
\hline 18 & Lake_Argyle & -16.11 & 128.75 & 150.00 & 2137 & 1.71 & 0.09 & 1.66 \\
\hline 19 & Lanai & 20.74 & -156.92 & 20.00 & 1530 & 1.76 & 0.08 & 2.87 \\
\hline 20 & Malaga & 36.72 & -4.48 & 40.00 & 1554 & 1.88 & 0.15 & 1.67 \\
\hline 21 & Maricopa & 33.07 & -111.97 & 360.00 & 1670 & 1.80 & 0.09 & 1.37 \\
\hline
\end{tabular}




\begin{tabular}{|c|c|c|c|c|c|c|c|c|}
\hline 22 & Mongu & -15.25 & 23.15 & 1107.00 & 1488 & 1.55 & 0.22 & 1.65 \\
\hline 23 & Mussafa & 24.37 & 54.47 & 10.00 & 1357 & 1.74 & 0.35 & 2.07 \\
\hline 24 & Pretoria_CSIR-DPSS & -25.76 & 28.28 & 1449.00 & 1511 & 1.59 & 0.17 & 1.11 \\
\hline 25 & Railroad_Valley & 38.50 & -115.96 & 1435.00 & 1974 & 1.63 & 0.06 & 0.71 \\
\hline 26 & Santa_Cruz_Tenerife & 30.86 & 34.78 & 480.00 & 1922 & 1.67 & 0.17 & 1.42 \\
\hline 27 & SEDE_BOKER & 28.47 & -16.25 & 52.00 & 1483 & 1.69 & 0.16 & 1.95 \\
\hline 28 & Sevilleta & 34.36 & -106.89 & 1477.00 & 1830 & 1.58 & 0.08 & 0.91 \\
\hline 29 & Solar_Village & 24.91 & 46.40 & 764.00 & 1754 & 1.57 & 0.31 & 1.13 \\
\hline 30 & Table_Mountain & 40.13 & -105.24 & 1689.00 & 1428 & 1.68 & 0.08 & 0.89 \\
\hline 31 & Tamanrasset_INM & 22.79 & 5.53 & 1377.00 & 1998 & 1.51 & 0.16 & 0.65 \\
\hline 32 & Toronto & 43.97 & -79.47 & 300.00 & 951 & 1.92 & 0.14 & 1.18 \\
\hline 33 & White_Sands_HELSTF & 32.64 & -106.34 & 1207.00 & 1740 & 1.69 & 0.08 & 0.98 \\
\hline 34 & Yonsei_University & 37.56 & 126.94 & 88.00 & 681 & 2.04 & 0.33 & 0.96 \\
\hline
\end{tabular}

Table 3 List of the 34 AERONET stations selected in this work, including annually DNI-weighted ( $\overline{\mathrm{SMR}}$ ) for each location at solar cell temperature of $25{ }^{\circ} \mathrm{C}$ and $90{ }^{\circ} \mathrm{C}$ (Analysis has considered $90^{\circ} \mathrm{C}$ values). Sites highlighted in bold are those used in the model in paragraph 4.3.

\begin{tabular}{|c|c|c|c|c|c|c|c|c|c|c|c|c|c|c|c|c|c|}
\hline \multirow[b]{3}{*}{ No } & \multirow[b]{3}{*}{ Location } & \multicolumn{4}{|c|}{ LM-Ge } & \multicolumn{4}{|c|}{ UMM } & \multicolumn{4}{|c|}{ IMM } & \multicolumn{4}{|c|}{ LM-DN } \\
\hline & & \multicolumn{2}{|c|}{$\overline{\mathrm{SMR}}_{\text {mid }}^{\mathrm{top}}$} & \multicolumn{2}{|c|}{$\overline{\mathrm{SMR}}_{\mathrm{bot}}^{\text {mid }}$} & \multicolumn{2}{|c|}{$\overline{\mathrm{SMR}}_{\text {mid }}^{\text {top }}$} & \multicolumn{2}{|c|}{$\overline{\mathrm{SMR}}_{\mathrm{bot}}^{\mathrm{mid}}$} & \multicolumn{2}{|c|}{$\overline{\mathrm{SMR}}_{\text {mid }}^{\mathrm{top}}$} & \multicolumn{2}{|c|}{$\overline{\mathrm{SMR}}_{\mathrm{bot}}^{\text {mid }}$} & \multicolumn{2}{|c|}{$\overline{\mathrm{SMR}}_{\text {mid }}^{\text {top }}$} & \multicolumn{2}{|c|}{$\overline{\mathrm{SMR}}_{\mathrm{bot}}^{\operatorname{mid}}$} \\
\hline & & $25^{\circ} \mathrm{C}$ & $90^{\circ} \mathrm{C}$ & $25^{\circ} \mathrm{C}$ & $90^{\circ} \mathrm{C}$ & $25^{\circ} \mathrm{C}$ & $90^{\circ} \mathrm{C}$ & $25^{\circ} \mathrm{C}$ & $90^{\circ} \mathrm{C}$ & $25^{\circ} \mathrm{C}$ & $90^{\circ} \mathrm{C}$ & $25^{\circ} \mathrm{C}$ & $90^{\circ} \mathrm{C}$ & $25^{\circ} \mathrm{C}$ & $90^{\circ} \mathrm{C}$ & $25^{\circ} \mathrm{C}$ & $90^{\circ} \mathrm{C}$ \\
\hline- & Bahrain & 0.896 & 0.896 & 0.935 & 0.932 & 0.895 & 0.897 & 0.932 & 0.928 & 0.898 & 0.898 & 0.960 & 0.960 & 0.894 & 0.894 & 0.953 & 0.955 \\
\hline 2 & Bari_University & 0.929 & 0.930 & 0.996 & 0.991 & 0.933 & 0.940 & 0.987 & 0.976 & 0.930 & 0.932 & 1.011 & 1.011 & 0.926 & 0.927 & 1.000 & 1.004 \\
\hline 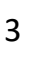 & Burjassot & 0.921 & 0.923 & 0.994 & 0.990 & 0.925 & 0.930 & 0.987 & 0.977 & 0.923 & 0.924 & 1.006 & 1.007 & 0.919 & 0.919 & 0.998 & 1.002 \\
\hline 4 & Cordoba-CETT & 0.971 & 0.971 & 0.994 & 0.994 & 0.971 & 0.971 & 0.993 & 0.992 & 0.971 & 0.971 & 0.996 & 0.997 & 0.970 & 0.970 & 0.995 & 0.997 \\
\hline 5 & Dhadnah & 0.883 & 0.884 & 0.944 & 0.939 & 0.885 & 0.890 & 0.937 & 0.927 & 0.886 & 0.886 & 0.973 & 0.973 & 0.881 & 0.881 & 0.962 & 0.965 \\
\hline
\end{tabular}



11 12
Egbert

Evora

Fresno

Fresno_2 Granada

Halifax

IMAA_Potenza

IMS-METU-ERDEMLI

Jabiru

Kelowna

Kelowna_UAS

Kirtland AFB

Lake_Argyle

Lanai

Malaga

Maricopa

Mongu

Mussafa

Pretoria_CSIR-DPSS

Railroad_Valley

Santa_Cruz_Tenerife

SEDE_BOKER

Sevilleta

Solar_Village

Table_Mountain

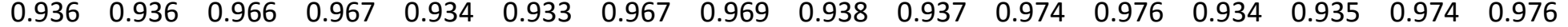

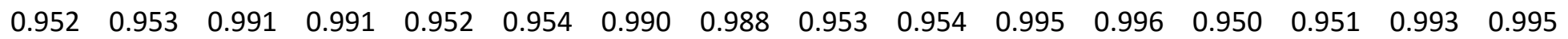

$\begin{array}{llllllllllllllll}0.947 & 0.948 & 0.988 & 0.987 & 0.948 & 0.951 & 0.985 & 0.982 & 0.949 & 0.949 & 0.995 & 0.996 & 0.946 & 0.946 & 0.992 & 0.994\end{array}$

$\begin{array}{llllllllllllllllll}0.955 & 0.956 & 0.989 & 0.989 & 0.956 & 0.957 & 0.988 & 0.985 & 0.956 & 0.957 & 0.995 & 0.996 & 0.954 & 0.954 & 0.993 & 0.995\end{array}$

$\begin{array}{lllllllllllllllll}0.936 & 0.936 & 0.959 & 0.960 & 0.934 & 0.933 & 0.961 & 0.963 & 0.938 & 0.937 & 0.969 & 0.970 & 0.935 & 0.935 & 0.969 & 0.970\end{array}$

$\begin{array}{llllllllllllllll}0.935 & 0.935 & 0.978 & 0.978 & 0.934 & 0.935 & 0.978 & 0.978 & 0.937 & 0.937 & 0.984 & 0.986 & 0.933 & 0.933 & 0.983 & 0.985\end{array}$

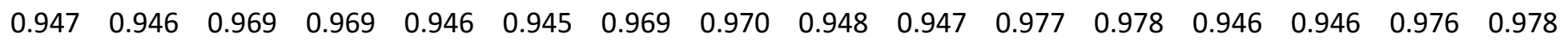

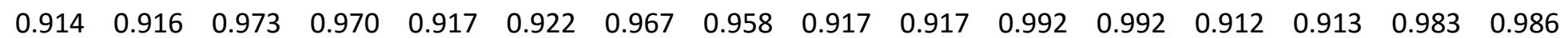

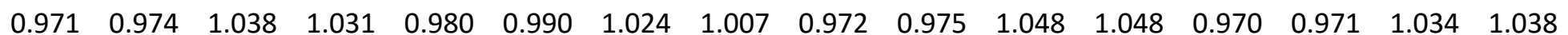

$\begin{array}{llllllllllllllll}0.926 & 0.926 & 0.973 & 0.974 & 0.925 & 0.925 & 0.974 & 0.973 & 0.928 & 0.927 & 0.979 & 0.981 & 0.923 & 0.924 & 0.978 & 0.981\end{array}$

$\begin{array}{llllllllllllllll}0.950 & 0.950 & 0.987 & 0.987 & 0.950 & 0.951 & 0.986 & 0.985 & 0.951 & 0.951 & 0.991 & 0.993 & 0.948 & 0.949 & 0.990 & 0.992\end{array}$

$\begin{array}{lllllllllllllllll}0.976 & 0.974 & 0.941 & 0.946 & 0.969 & 0.960 & 0.950 & 0.963 & 0.976 & 0.974 & 0.944 & 0.946 & 0.977 & 0.976 & 0.954 & 0.952\end{array}$

$\begin{array}{lllllllllllllllll}0.984 & 0.984 & 1.002 & 1.001 & 0.985 & 0.986 & 1.000 & 0.998 & 0.984 & 0.985 & 1.005 & 1.006 & 0.983 & 0.984 & 1.003 & 1.004\end{array}$

$\begin{array}{llllllllllllllll}1.003 & 1.007 & 1.081 & 1.071 & 1.015 & 1.029 & 1.062 & 1.039 & 1.003 & 1.006 & 1.084 & 1.084 & 1.001 & 1.003 & 1.067 & 1.072\end{array}$

$\begin{array}{llllllllllllllll}0.939 & 0.939 & 0.989 & 0.987 & 0.940 & 0.943 & 0.985 & 0.980 & 0.940 & 0.941 & 0.997 & 0.998 & 0.937 & 0.937 & 0.993 & 0.995\end{array}$

$\begin{array}{lllllllllllllllll}0.964 & 0.963 & 0.982 & 0.983 & 0.962 & 0.961 & 0.983 & 0.985 & 0.964 & 0.964 & 0.985 & 0.986 & 0.962 & 0.963 & 0.986 & 0.987\end{array}$

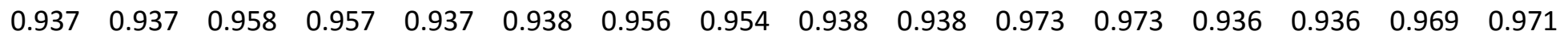

$\begin{array}{llllllllllllllll}0.873 & 0.874 & 0.937 & 0.933 & 0.874 & 0.879 & 0.931 & 0.922 & 0.876 & 0.876 & 0.966 & 0.967 & 0.871 & 0.871 & 0.956 & 0.959\end{array}$

$\begin{array}{llllllllllllllll}0.938 & 0.936 & 0.934 & 0.937 & 0.933 & 0.928 & 0.940 & 0.946 & 0.939 & 0.938 & 0.946 & 0.947 & 0.938 & 0.937 & 0.949 & 0.950\end{array}$

$\begin{array}{llllllllllllllll}0.978 & 0.975 & 0.936 & 0.943 & 0.970 & 0.959 & 0.948 & 0.963 & 0.978 & 0.976 & 0.939 & 0.941 & 0.979 & 0.978 & 0.950 & 0.949\end{array}$

$\begin{array}{llllllllllllllll}0.941 & 0.941 & 0.961 & 0.962 & 0.940 & 0.940 & 0.962 & 0.963 & 0.943 & 0.942 & 0.972 & 0.973 & 0.941 & 0.941 & 0.971 & 0.972\end{array}$

$\begin{array}{llllllllllllllllll}0.959 & 0.960 & 1.003 & 1.000 & 0.962 & 0.967 & 0.996 & 0.988 & 0.960 & 0.961 & 1.012 & 1.013 & 0.957 & 0.958 & 1.005 & 1.008\end{array}$

$\begin{array}{lllllllllllllllll}0.976 & 0.974 & 0.944 & 0.949 & 0.970 & 0.962 & 0.953 & 0.965 & 0.977 & 0.975 & 0.948 & 0.950 & 0.977 & 0.976 & 0.957 & 0.956\end{array}$

$\begin{array}{llllllllllllllllll}0.889 & 0.887 & 0.895 & 0.897 & 0.883 & 0.878 & 0.901 & 0.908 & 0.892 & 0.890 & 0.917 & 0.918 & 0.888 & 0.887 & 0.919 & 0.920\end{array}$ $\begin{array}{llllllllllllllllll}0.965 & 0.963 & 0.944 & 0.948 & 0.958 & 0.950 & 0.953 & 0.964 & 0.965 & 0.963 & 0.947 & 0.949 & 0.965 & 0.964 & 0.956 & 0.955\end{array}$ 


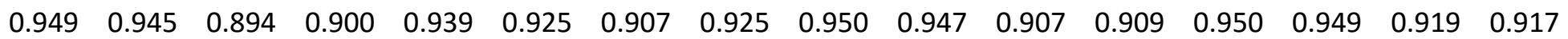

Toronto

$\begin{array}{llllllllllllllll}0.923 & 0.922 & 0.943 & 0.946 & 0.918 & 0.915 & 0.948 & 0.954 & 0.924 & 0.923 & 0.953 & 0.955 & 0.921 & 0.921 & 0.956 & 0.958\end{array}$

White_Sands_HELSTF

$\begin{array}{lllllllll}0.969 & 0.967 & 0.952 & 0.956 & 0.964 & 0.957 & 0.959 & 0.969\end{array}$

Yonsei_University

$\begin{array}{llll}0.823 & 0.820 & 0.846 & 0.851\end{array}$

$0.8130 .805 \quad 0.856 \quad 0.868$

$\begin{array}{lllllllll} & 0.968 & 0.955 & 0.957 & 0.969 & 0.968 & 0.962 & 0.962\end{array}$ . 


\section{REFERENCES}

[1] S. P. Philipps, A. W. Bett, K. Horowitz, and S. Kurtz, "Current status of concentrator photovoltaic (CPV) technology v1.2,” NREL \& Fraunhofer ISE, TP-6A20-63916, Feb. 2016.

[2] K. Araki and M. Yamaguchi, "Influences of spectrum change to 3-junction concentrator cells," Sol. Energy Mater. Sol. Cells, vol. 75, no. 3-4, pp. 707-714, Feb. 2003.

[3] S. R. Kurtz and M. J. O’Neill, “Estimating and controlling chromatic aberration losses for two-junction, two-terminal devices in refractive concentrator systems," in Conference Record of the Twenty Fifth IEEE Photovoltaic Specialists Conference, 1996, 1996, pp. 361-364.

[4] C. A. Gueymard, "Spectral Circumsolar Radiation Contribution To CPV," in AIP Conference Proceedings, 2010, vol. 1277, pp. 316-319.

[5] K. Emery, M. Meusel, R. Beckert, F. Dimroth, A. Bett, and W. Warta, "Procedures for evaluating multijunction concentrators," in Conference Record of the Twenty-Eighth IEEE Photovoltaic Specialists Conference, 2000, 2000, pp. 1126-1130.

[6] C. Domínguez, I. Antón, G. Sala, and S. Askins, "Current-matching estimation for multijunction cells within a CPV module by means of component cells: Current-matching estimation for MJ cells within a concentrator," Prog. Photovolt. Res. Appl., vol. 21, no. 7, pp. 1478-1488, Nov. 2013.

[7] Jaus, J., "Spectral Measurements Using Component Cells: Examinations on Measurement Precision," in 26th European Photovoltaic Solar Energy Conference and Exhibition, EU PVSEC. Proceedings, 2011, pp. 176-181.

[8] G. Peharz, G. Siefer, K. Araki, and A. W. Bett, "Spectrometric outdoor characterization of CPV modules using isotype monitor cells," in 33rd IEEE Photovoltaic Specialists Conference, 2008. PVSC '08, 2008, pp. 1-5.

[9] R. Núñez, C. Domínguez, S. Askins, M. Victoria, R. Herrero, I. Antón, and G. Sala, "Determination of spectral variations by means of component cells useful for CPV rating and design," Prog. Photovolt. Res. Appl., p. n/a-n/a, 2015.

[10] G. Siefer, M. Steiner, M. Baudrit, C. Dominguez, I. Antón, R. Núñez, F. Roca, P. M. Pugliatti, A. D. Stefano, R. Kenny, and P. Morabito, "SOPHIA CPV module round robin: Power rating at CSOC," in AIP Conference Proceedings, 2014, vol. 1616, pp. 167-172.

[11] I. Antón, M. Martínez, F. Rubio, R. Núñez, R. Herrero, C. Domínguez, M. Victoria, S. Askins, and G. Sala, "Power rating of CPV systems based on spectrally corrected DNI," in AIP Conference Proceedings, 2012, vol. 1477, pp. 331-335.

[12] N. L. A. Chan, H. E. Brindley, and N. J. Ekins-Daukes, "Impact of individual atmospheric parameters on CPV system power, energy yield and cost of energy," Prog. Photovolt. Res. Appl., vol. 22, no. 10, pp. 1080-1095, Oct. 2014.

[13] C. A. Gueymard, "Parameterized transmittance model for direct beam and circumsolar spectral irradiance," Sol. Energy, vol. 71, no. 5, pp. 325-346, Nov. 2001.

[14] P. Faine, S. R. Kurtz, C. Riordan, and J. M. Olson, "The influence of spectral solar irradiance variations on the performance of selected single-junction and multijunction solar cells," Sol. Cells, vol. 31, no. 3, pp. 259-278, Jun. 1991.

"This is the peer reviewed version of the following article: R. Núñez, C. Jin, M. Victoria, C. Domínguez, S. Askins, R. Herrero, I. Antón, and G. Sala, "Spectral study and classification of worldwide locations considering several multijunction solar cell technologies: Spectral study and classification of worldwide locations," Prog. Photovolt: Res. Appl.., 2016, which has been published in final form at http://onlinelibrary.wiley.com/doi/10.1002/pip.2781/full. This article may be used for non-commercial purposes in accordance with Wiley Terms and Conditions for Self-Archiving

[http://olabout.wiley.com/WileyCDA/Section/id-820227.htm/\#terms]." 
[15] K. M. Armijo, R. K. Harrison, B. H. King, and J. B. Martin, "Spectral derates phenomena of atmospheric components on multi-junction CPV technologies," in AIP Conference Proceedings, 2014, vol. 1616, pp. 264-271.

[16] C. A. Gueymard, "Daily spectral effects on concentrating PV solar cells as affected by realistic aerosol optical depth and other atmospheric conditions," in Optical Modeling and Measurements for Solar Energy Systems III, 2009, vol. 7410, pp. 741007-741007-14.

[17] K. Emery, D. Myers, and S. Kurtz, "What is the appropriate reference spectrum for characterizing concentrator cells?," in Conference Record of the Twenty-Ninth IEEE Photovoltaic Specialists Conference, 2002, 2002, pp. 840-843.

[18] S. P. Philipps, G. Peharz, R. Hoheisel, T. Hornung, N. M. Al-Abbadi, F. Dimroth, and A. W. Bett, "Energy harvesting efficiency of III-V triple-junction concentrator solar cells under realistic spectral conditions,” Sol. Energy Mater. Sol. Cells, vol. 94, no. 5, pp. 869-877, May 2010.

[19] K. Emery, J. Delcueto, and W. Zaaiman, "Spectral corrections based on optical air mass," in Conference Record of the Twenty-Ninth IEEE Photovoltaic Specialists Conference, 2002, 2002, pp. 1725-1728.

[20] C. R. Osterwald, K. A. Emery, and M. Muller, "Photovoltaic module calibration value versus optical air mass: the air mass function," Prog. Photovolt. Res. Appl., vol. 22, no. 5, pp. 560-573, May 2014.

[21] E. F. Fernández, F. Almonacid, J. A. Ruiz-Arias, and A. Soria-Moya, “Analysis of the spectral variations on the performance of high concentrator photovoltaic modules operating under different real climate conditions," Sol. Energy Mater. Sol. Cells, vol. 127, pp. 179-187, Aug. 2014.

[22] P. A. Hubanks, M. D. King, S. Platnick, and R. Pincus, "MODIS atmosphere L3 gridded product algorithm theoretical basis document," NASA Goddard Space Flight Cent., Greenbelt, MD, 2008.

[23] R. W. Mueller, K. F. Dagestad, P. Ineichen, M. Schroedter-Homscheidt, S. Cros, D. Dumortier, R. Kuhlemann, J. A. Olseth, G. Piernavieja, C. Reise, L. Wald, and D. Heinemann, "Rethinking satellite-based solar irradiance modelling: The SOLIS clear-sky module," Remote Sens. Environ., vol. 91, no. 2, pp. 160-174, May 2004.

[24] T. Behrendt, J. Kuehnert, A. Hammer, E. Lorenz, J. Betcke, and D. Heinemann, "Solar spectral irradiance derived from satellite data: A tool to improve thin film PV performance estimations?," Sol. Energy, vol. 98, Part B, pp. 100-110, Dec. 2013.

[25] B. N. Holben, T. F. Eck, I. Slutsker, D. Tanre, J. P. Buis, A. Setzer, E. Vermote, J. A. Reagan, Y. J. Kaufman, and T. Nakajima, “AERONET -A federated instrument network and data archive for aerosol characterization,” Remote Sens. Environ., vol. 66, no. 1, pp. 1-16, 1998.

[26] J. Jaus and C. A. Gueymard, "Generalized spectral performance evaluation of multijunction solar cells using a multicore, parallelized version of SMARTS," in AIP Conference Proceedings, 2012, vol. 1477, pp. 122-126.

[27] R. Núñez, I. Antón, S. Askins, and G. Sala, "Atmospheric parameters, spectral indexes and their relation to CPV spectral performance," in AIP Conference Proceedings, 2014, vol. 1616, pp. $290-293$. 
[28] M. Victoria, R. Herrero, C. Domínguez, S. Askins, I. Antón, and G. Sala, “Indoor characterization of non uniform light distribution due to concentration optics and its effects on solar cell performance," in 25th European Photovoltaic Solar Energy Conference and Exhibition - 5th World Conference on Photovoltaic Energy Conversion, Valencia, Spain, 2010, pp. 143-146.

[29] T. Hornung, M. Steiner, and P. Nitz, "Estimation of the influence of Fresnel lens temperature on energy generation of a concentrator photovoltaic system," Sol. Energy Mater. Sol. Cells, vol. 99, pp. 333-338, Apr. 2012.

[30] S. Askins, M. Victoria, R. Herrero, C. Domínguez, I. Antón, G. Sala, F. Dimroth, S. Kurtz, G. Sala, and A. W. Bett, "Effects of Temperature on Hybrid Lens Performance," in AIP Conference Proceedings, 2011, vol. 1407, pp. 57-60.

[31] A. Bayat, A. Masoumi, and H. R. Khalesifard, "Retrieval of atmospheric optical parameters from ground-based sun-photometer measurements for Zanjan, Iran,” Atmospheric Meas. Tech., vol. 4, no. 5, pp. 857-863, May 2011.

[32] G. E. Shaw, “Sun Photometry,” Bull. Am. Meteorol. Soc., vol. 64, no. 1, pp. 4-10, Jan. 1983.

[33] V. Estellés, M. P. Utrillas, J. A. Martínez-Lozano, A. Alcántara, L. Alados-Arboledas, F. J. Olmo, J. Lorente, X. de Cabo, V. Cachorro, H. Horvath, A. Labajo, M. Sorribas, J. P. Díaz, A. M. Díaz, A. M. Silva, T. Elías, M. Pujadas, J. A. Rodrigues, J. Cañada, and Y. García, “Intercomparison of spectroradiometers and Sun photometers for the determination of the aerosol optical depth during the VELETA-2002 field campaign,” J. Geophys. Res., vol. 111, no. D17, 2006.

[34] “ASTM G173 standard tables for reference solar spectral irradiances,” vol. AM15D.

[35] R. Núñez, I. Antón, S. Askins, G. Sala, C. Domínguez, P. Voarino, M. Steiner, G. Siefer, R. Fucci, F. Roca, A. Minuto, and P. Morabito, "Spectral network based on component cells under the SOPHIA European project," in AIP Conference Proceedings, 2015, vol. 1679, p. 030006.

[36] B. N. Holben, T. F. Eck, I. Slutsker, A. Smirnov, A. Sinyuk, J. Schafer, D. Giles, and O. Dubovik, “AERONET's version 2.0 quality assurance criteria,” in Asia-Pacific Remote Sensing Symposium, 2006, p. 64080Q-64080Q.

[37] F. Kasten and A. T. Young, "Revised optical air mass tables and approximation formula," Appl. Opt., vol. 28, no. 22, pp. 4735-4738, Nov. 1989.

[38] M. Muller, B. Marion, S. Kurtz, and J. Rodriguez, “An investigation into spectral parameters as they impact CPV module performance," in AIP Conference Proceedings, 2010, vol. 1277, p. 307.

[39] S. Park, H. El-Askary, I. Sabbah, H. Kwak, A. K. Prasad, W.-K. Lee, and M. Kafatos, "Studying Air Pollutants Origin and Associated Meteorological Parameters over Seoul from 2000 to 2009," Adv. Meteorol., vol. 2015, p. e704178, Mar. 2015.

[40] C. Guirado, E. Cuevas, V. E. Cachorro, C. Toledano, S. Alonso-Pérez, J. J. Bustos, S. Basart, P. M. Romero, C. Camino, M. Mimouni, L. Zeudmi, P. Goloub, J. M. Baldasano, and A. M. de Frutos, "Aerosol characterization at the Saharan AERONET site Tamanrasset," Atmos Chem Phys, vol. 14, no. 21, pp. 11753-11773, Nov. 2014.

[41] S. Yoon, S. Lee, and I. Choi, "Comparison of Asian aerosol's radiative effect in Seoul and Gosan, Korea," in AGU Spring Meeting Abstracts, 2007, vol. 1, p. 07.

"This is the peer reviewed version of the following article: R. Núñez, C. Jin, M. Victoria, C. Domínguez, S. Askins, R. Herrero, I. Antón, and G. Sala, "Spectral study and classification of worldwide locations considering several multijunction solar cell technologies: Spectral study and classification of worldwide locations," Prog. Photovolt: Res. Appl., 2016, which has been published in final form at http://onlinelibrary.wiley.com/doi/10.1002/pip.2781/full. This article may be used for non-commercial purposes in accordance with Wiley Terms and Conditions for Self-Archiving [http://olabout.wiley.com/WileyCDA/Section/id-820227.html/\#terms]." 
[42] M. Victoria, S. Askins, R. Núñez, C. Domínguez, R. Herrero, I. Antón, G. Sala, and J. M. Ruíz, "Tuning the current ratio of a CPV system to maximize the energy harvesting in a particular location," in AIP Conference Proceedings, 2013, vol. 1556, p. 156.

[43] D. Aiken, M. Stan, C. Murray, P. Sharps, J. Hills, and B. Clevenger, "Temperature dependent spectral response measurements for III-V multi-junction solar cells," in Conference Record of the Twenty-Ninth IEEE Photovoltaic Specialists Conference, 2002, 2002, pp. 828-831.

[44] F. Pérez, B. E. Granger, and J. D. Hunter, "Python: An Ecosystem for Scientific Computing," Comput. Sci. Eng., vol. 13, no. 2, pp. 13-21, Mar. 2011. 